NUREG/CR-1675

BNL-NUREG-51262

\title{
EXPERIMENTAL INVESTIGATION OF THE SCC OF INCONEL 600 AND A PREDICTIVE MODEL FOR EVALUATING SERVICE PERFORMANCE
}

\author{
T.S. BULISCHECK AND D. van ROOYEN \\ QO I.UT MICROFILM \\ COVER
}

July 1980

CORROSION SCIENCE GROUP

DEPARTMENT OF NUCLEAR ENERGY, BROOKHAVEN NATIONAL LABORATORY UPTON, NEW YORK 11973 


\section{DISCLAIMER}

This report was prepared as an account of work sponsored by an agency of the United States Government. Neither the United States Government nor any agency Thereof, nor any of their employees, makes any warranty, express or implied, or assumes any legal liability or responsibility for the accuracy, completeness, or usefulness of any information, apparatus, product, or process disclosed, or represents that its use would not infringe privately owned rights. Reference herein to any specific commercial product, process, or service by trade name, trademark, manufacturer, or otherwise does not necessarily constitute or imply its endorsement, recommendation, or favoring by the United States Government or any agency thereof. The views and opinions of authors expressed herein do not necessarily state or reflect those of the United States Government or any agency thereof. 


\section{DISCLAIMER}

Portions of this document may be illegible in electronic image products. Images are produced from the best available original document. 


\title{
EXPERIMENTAL INVESTIGATION OF THE SCC OF INCONEL 600 AND A PREDICTIVE MODEL FOR EVALUATING SERVICE PERFORMANCE
}

\author{
T.S. BULISCHECK AND D. VAN ROOYEN
}

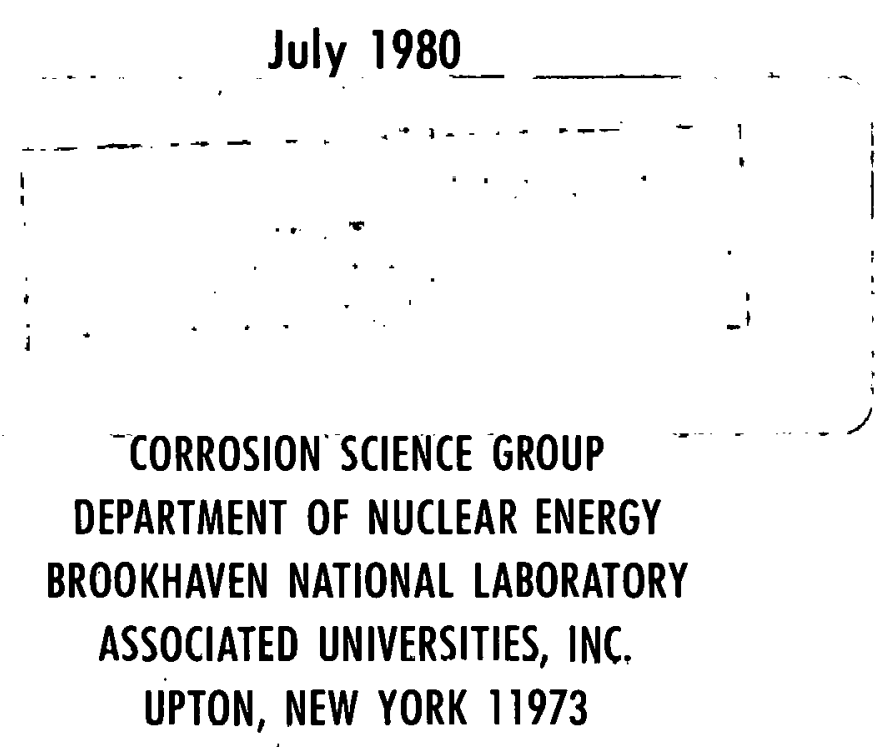

PREPARED FOR THE UNITED STATES NUCLEAR REGULATORY COMMISSION DIVISION OF REACTOR SAFETY RESEARCH, OFFICE OF NUCLEAR REGULATORY RESEARCH UNDER CONTRACT NO. DE-AC02-76CH00016 NRC FIN NO. A-3208 


\section{DISCLAIMER}

This report was prepared as an account of work sponsored by an agency of the United States Government. Neither the United States Government nor any agency thereof, nor any of their employees, makes any warranty, express or implied, or assumes any legal liability or responsibility for the accuracy, completeness, or usefulness of any information, apparatus, product, or process disclosed, or represents that its use would not infringe privately owned rights. Reference herein to any specific commercial product, process, or service by trade name, trademark, manufacturer, or otherwise does not necessarily constitute or imply its endorsement, recommendation, or favoring by the United States Government or any agency thereof. The views and opinions of authors expressed herein do not necessarily state or reflect those of the United States Government or any agency thereof.

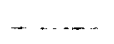

\section{NOTICF}

This report was prepared as an account of work sponsored by an agency of the United States Government. Neither the United States Government nor any agency thcrcof, or any of their employees, makes any warranty, expressed or implied, or assumes any legal liability or responsibility for any third party's use, or the results of such use, of any information, apparatus, product or process disclosed in this report, or represents that its use by such third party would not infringe privately owned rights.

The views expressed in this report are not necessarily those of the U.S. Nuclear Regulatory Commission.

Available from

GPO Sales Program

Division of Technical Information and Document Control

U.S. Nuclear Regulatory Commission

Washington, D.C. 20555

and

National Technical Information Service

Springfield, Virginia 22161 


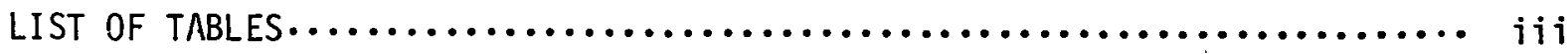

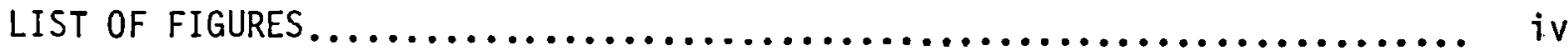

ABSTRACT $\ldots \ldots \ldots \ldots \ldots \ldots \ldots \ldots \ldots \ldots \ldots \ldots \ldots \ldots \ldots \ldots \ldots \ldots \ldots \ldots \ldots \ldots$

Section $A \quad$ INTRODUCTION................................ I

Section B BASIC SIMPLE MODEL FOR QUANTITATIVE RELATIONSHIPS

IN SCC INITIATION.............................. I

B-1 Increase of Temperature and Stress with Constant

Load or Constant Deflection......................... I

Section C BASIC MODEL FOR QUANTITATIVE RELATIONSHIPS IN CRACK

PROPAGATION.................................... 3

C-1 Increased Temperature Combined with Constant Extension Rate 3

C-2 Increased Temperature Combined with Applied Stress and

Superimposed Cyclic Stress........................ 3

Section $D \quad$ PRACTICAL SIGNIFICANCE....................... 4

Section E COMPLICATING FACTORS AND MODIFICATIONS TO THE BASIC EQUATION 4

E-1 Surface Condition........................... 5

E-2 Metallurgical Condition....................... 5

E-3 Environmental Variables........................ 7

E-4 0ther Test Variables........................... 8

Section $F \quad$ EXPERIMENTAL DETAILS......................... 9

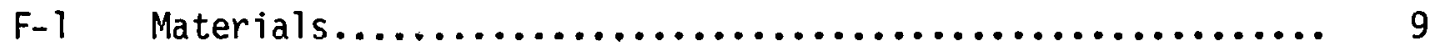

F-2 Specimen Preparation.......................... 10

F-3 Test Environment.............................. 10

Section $G$ EXPERIMENTAL DETERMINATION OF CRACK INITIATION IN

STATICALLY STRESSED SPECIMENS.................... 11

G-1 Constant Deflection Tests...................... 11

G-2 Constant Stress Tests........................ 13

Section $H$ EXPERIMENTAL DETERMINATION OF CRACK PROPAGATION IN

DYNAMICALLY STRESSED SPECIMENS $\ldots \ldots \ldots \ldots \ldots \ldots \ldots \ldots \ldots \ldots \ldots 14$ 
H-1 Constant Extension Rate Tests (CERT) ................ 14

H-2 Cyclic Load Test............................ 15

DISCUSSION.............................. 16 
TABLE 1 Mechanical Properties and Chemical Composition of Test Materials....................................... 18

TABLE 2 Nitrogen Content and Average Failure Times of Inconel $600 . \ldots . . .19$

TABLE 3 Specimens Fabricated from Ingot and Exposed $0365^{\circ} \mathrm{C} \ldots \ldots \ldots \ldots$

TABLE 4 Specimens Fabricated from Plate and Exposed $\Theta 365^{\circ} \mathrm{C} \ldots \ldots \ldots \ldots . \ldots 21$

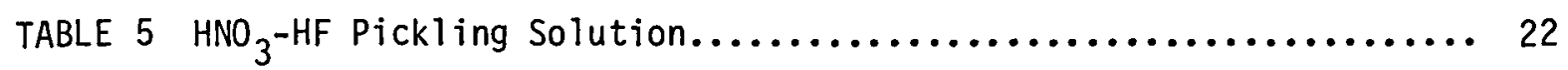

TABLE 6 Treatment of Cold Worked Tubing before Forming into U-bend

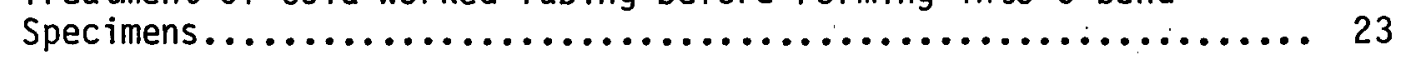

TABLE 7 Materials Experiencing IGSCC in U-bend Tests............... 24

TABLE 7a Materials Experiencing IGSCC IN U-bend Tests............... 25

TABLE 8 Results of Cyclic Load Tests in D.I. $\mathrm{H}_{2} \mathrm{O}$ at $365^{\circ} \mathrm{C} \ldots \ldots \ldots \ldots \ldots 26$ 
Figure 1 Effect of environment, surface preparation and temperature on failure time of U-bend specimens (A) Heat. \#4

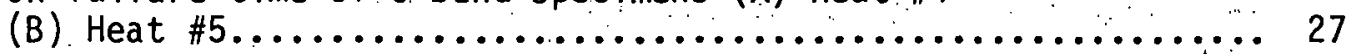

Figure 2 Effect of environment, surface preparation and temperature on failure time of U-bend specimens (A) Heat \#10

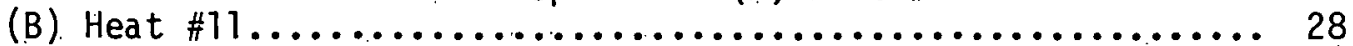

Figure 3 .. Effect of énvironment, surface preparation and temperature on failure time of U-bend specimens Heat $\# 2 \ldots . \ldots \ldots \ldots \ldots \ldots . \ldots 29$

Figure 4 Effect of carbon content on activation energy............. 29

Figure 5. Micrographs of 2 susceptible materials cracked in pure water at $365^{\circ},(A)$ Heat $\# 2(B)$ Heat $\# 5 \ldots \ldots \ldots \ldots \ldots \ldots \ldots \ldots \ldots \ldots . . . \ldots$

Figure 6 Micrographs of 2 non-susceptible heats of material (A)

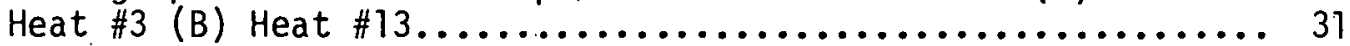

Figure 7 Structure of recently manufactured material removed from fabrication prior to thermal treatment. Materials have cracked in AVT and/or primary $\mathrm{H}_{2} \mathrm{O}$ (A) Heat \#18 (B) Heat \#20.... 32

Figure 8 Preliminary constant stress test results with Heat \#4

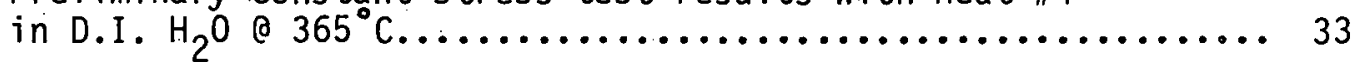

Figure 9 Effect of strain rate on crack velocity................ 34

Figure 10 Effect of temperature on crack velocity for materials tested in C.E.R.T....................................... 35 
A research program currently in progress at Brookhaven National Laboratory has produced quantitative data on the various factors which may influence the service life of Inconel 600 steam generator tubing. A basic model is presented to relate data produced using accelerated test methods to actual service conditions. The effects of temperature, environment, stress, strain and strain rate on a number of heats of mill annealed material and tubing with beneficial heat treatments are presented. The initiation and propagation stages of intergranular stress corrosion cracking are treated separately. Although crack initiation time is altered by different chemical environments or perhaps composition, the crack growth rates appear to be governed by a temperature dependent process. 


\section{A. Introduction}

NUREG/CR-0858 BNL-NUREG-51027 of June, 1979 described the initial work that was done under this contract for RSR on the stress corrosion cracking (SCC) of Inconel 600. This earlier work included the identification of several production type tube samples of Inconel 600 that were susceptible to SCC in high temperature deaerated water. It also included the initial quantitative relationships with temperature and certain effects such as that of cold work.

The present report extends the discussion of the results that have been obtained, and it also extends the framework within which the results are interpreted in order to indicate how they would be used to predict the lifetime of tubing that is subjected to the complex environment and other factors in service.

Basically, the work is divided into two parts, that is (a) the results obtained with static stresses such as U-bends and (b) the dynamically strained materials such as subjected to slow strain rate and to cyclic stresses. It is believed that these two distinct types of experiments deal with different aspects of the SCC process. It is believed that the U-bends provide a measure only of crack initiation time, because we take the time to failure as the time when the first visible crack appears. Our initial thought that the slow strain rate experiments entirely el iminated the induction period for SCC of Inconel in high temperature water has been modified. We now feel that the time involved in the facture by SCC of slowly straining specimens actually involves both an induction and a propagation phase of cracking. Attempts are now being made to find the cut-off point between these two phases so that they can be treated separately. Attempts are also being made to interpret the cyclic stresses in terms of slow strain rate experiments so as to permit a correlation of the slow strain rate tests with the ones in which the stresses are applied sinusoidally.

\section{B. Basic Simple Model for Quantitative Relationships in SCC Initiation}

To determine performance of an unknown material (e.g. a tube), we are using accelerated test conditions where the levels of temperature and stess are increased in order to reduce the test time. This is necessary, otherwise the laboratory evaluation will take too long.

\section{Increase of Temperature and Stress with Constant Load or Constant Deflection:}

These tests are intended to study the initiation period of SCC. (A correction will be made for the time taken for crack propagation, since the initiation is only the time until the first crack starts and our test 
includes the time for some growth of the crack. The method for making this correction will be based on values obtained from other experiments in which crack velocities are determined, and the total time to failure will be reduced accordingly. The results that have already been obtained will only change slightly, because initiation time is long compared to propagation time.)

The basis for using the accelerated test data is as follows. Temperature relates to crack initiation time according to the Arrhenius equation:

$$
V=t_{f}^{-1}=k \cdot \exp ^{-\frac{Q}{R T}}
$$

where: $\quad V=$ measure of reaction rate

$t_{f}=$ failure time (initiation)

$k=$ constant

$Q=$ activation energy

$\mathrm{R}=$ gas constant

$T=$ absolute temperature

Provided that the mechanism of crack initiation does not change over the temperature range that we are studying, the semi-log plot according to equation 1 will be a straight line. Obviously, then one can extrapolate either mathematically or graphically in order to determine the corresponding failure time at operating temperature once the time to failure at high temperature is established.

Similarly, a relationship between stress and time to failure is established and this is expressed in equation 2:

$$
v=t_{f}^{-1}=c o r^{b}
$$

where: $b, c=$ constants

$\sigma=$ stress

Equation 2 can be rewritten in the form of a straight line relationship between the $\log$ of the inverse failure time and the $\log$ of applied stress. The slope of the line will be given by constant b. This procedure, again, enables us to extrapolate either mathematically or graphically from the high test stress level to a pre-determined operating stress in order to determine the failure time from the accelerated test.

Combining equations 1 and 2 gives equation 3 :

$$
t_{f}-1=k \cdot \sigma b^{-} \exp -\frac{Q}{R T}
$$

where: $K=$ constant (including $k$ and $c$ )

Graphically, equations 1 and 2 would be used separately in order to determine the behavior of an unknown tube at operating temperature and stress. Mathematically it is possible to use equation 3 to determine in one step the failure time associated with certain simple operating conditions once the constant $K$ and activation energy and exponent $b$ are known. 
Equation 3 then forms the elementary basis of our quantitative relationship for determining SCC initiation. However, in practice we have to consider other conditions in addition to variations of temperature or stress. Some of these other factors that can, and do, affect SCC are discussed a little later.

\section{Basic Model for Quantitative Relationships in Crack Propagation}

Laboratory investigations have shown that when Inconel 600 is subjected to slow deformation rates, such as those that may be experienced by actively denting tubes, failure occurs much more rapidly than is indicated by constant deflection type specimens. It is assumed that a slip step emergence-film rupture mechanism is responsible for minimizing the crack initiation period and, therefore, providing a measure of crack propagation rates and service life expectancy for continually deforming tubes.

\section{Increased Temperature Combined with Constant Extension Rate}

In these tests, specimens are constantly extended at high temperature until failure occurs. Examination reveals the depth of SCC and an average crack velocity is determined by dividing the intergranular crack depth by the time of the experiment. The results can again be expressed in a relationship of the Arrehenius type as in equation 1 and the same extrapolation to operating temperature can then be made once the constant $k$ and the activation energy are established.

In the case of the slow strain experiment, the strain rate itself may be a variable that has to be considered as important because it may affect the crack velocity. Normally there is a range of strain rate over which crack velocity remains reasonably constant. It is very useful to determine the span of such a plateau so that the variability in crack velocity can be eliminated by choosing a strain rate, for experimental purposes, which falls within the constant velocity region. Our tests are establishing the existence of such a range of strain rates and this part of the research work is near completion.

\section{Increased Temperature Combined with Appl ied Stress and} Superimposed Cyclic Stress

Because tubes in service are subjected to a constant stress that may vary and are also subjected to cyclic stresses during operation, we are studying the effects of such combinations. In these tests, we apply a basic constant load and then superimpose a small cyclic stress on top of this basic load. The variables are the level of the initial load, the frequency, and the range through which the cyclic part of the stress is applied. In addition, some tests will determine the effect of the type of cyclic stress, including sinusoidal, sawtooth, or square wave.

As will be shown in the detailed experimental results, the initial tests have indicated practically no effect of changes in frequency within the range studied which has so far been $1 \mathrm{~Hz}$ to $10^{-3} \mathrm{~Hz}$. This has led us to the 
initial conclusion that the cyclic component is simply a variation on the same theme as the slow strain rate test. In other words, if the portion of the sinusoidal cyclic stress during which creep occurs is taken to be important in starting SCC, then a calculation of strain rate can easily be performed by measuring the total strain, which is known from the experiment. It remains to be established whether this argument is correct, and if found so, the interpretation of the cyclic experiments will be greatly simplified because they will be transferred to the same equation as used for the slow strain rate test. Some further definition, of course, is needed of the role of the initial applied stress level as well as its relation to the frequency and amplitude of the applied load.

\section{Practical Significance}

Item $C$ above gives the basis of the quantitative approach to the present research program. Item E, that follows, lists the various complicating factors that may alter or affect the basic relationship and will also contain details of how we intend to allow for variations caused by the complicating factors. The practical significance of the simple relationship in $B$ above is evident. Obviously, the constant load tests refer to conditions where a high stress is generated in a steam generator tube for instance through denting, rough handling or other cause. The cause is then removed, but the high stress remains and stays reasonably constant during long time service and we would like to know how safe this condition is.

The cyclic stress and the constant strain rate tests apply to conditions where either there are variable operating stresses that induce a degree of constant or cyclic creep, or where perhaps denting takes place to give periodic or continual deformation of the steam generator tubing. All of these conditions are very practical and should be addressed individually and applied to the simple basis for quantitative prediction in order to provide meaningful practical information. This calls for a good analysis of conditions that prevail in the field, so that we can make a specific selection of the correct set of curves or equations that apply to the particular operating circumstances.

\section{E. Complicating Factors and Modifications to the Basic Equation}

There are several factors which we are now considering in this regard, and they are listed below together with a more detailed outline of the tests planned to take them into account. In the final outcome, it is expected that a series of the constants and perhaps even changes in activation energies will become available for tabulation and selection according to the specific conditions for which a prediction in service is required. In other words, the modifications to the simple relationships that were given in section $B$ will be made (through the experimental determination of the relevant constants and exponents) and used for graphical or mathematical extrapolation from accelerated laboratory results to field conditions. 
Where it is necessary to make a determination of life expectancy of a tube under conditions which are not constant, such as for a tube exposed to a succession of different environments, stresses, or other conditions, each one will be taken into account separately and expressed as a fraction of the life of that tube that has been consumed by that particular set of conditions. In this manner, a cumulative fraction of the total life expectancy can be based on different variations and a prediction of future life can be based on a simple subtraction of these various fractions from the total expected lifetime of a tube.

The validity of the overall quantitative background to be set by our R\&D can only be tested against tubes of known performance in the field. For this purpose we will have to set up equipment that will be capable of handling radioactive tubes from service. Also, tubes with a known history and especially tubes that have cracked in service where conditions are reasonably well known, will have to be obtained for our tests. They will be subjected to chemical analysis and to one or two accelerated tests in the laboratory to determine their basic resistance to SCC and equations will be applied to predict from the accelerated tests what the expected time to failure would be in the field, for comparison with their actual performance. It may also be possible to obtain tubes that are or were placed in service (without any failure so far) and to predict from laboratory results how they would be expected to perform by feeding into the equations important variables as obtained from the field. The predictions can then be kept up-to-date until such time as in-service SCC is reported so that validity can be ascertained on a continuing basis. The latter "blind" prediction will provide the best evaluation of our quantitative equations.

It should be noted that the phenomenon has to be studied experimentally, because a theoretical prediction of the effects of the various factors is extremely difficult, if not impossible, due to the unknown nature of the mechanism of SCC in Inconel 600 in high temperature water.

\section{Surface condition:}

- In all of the tests that are being undertaken at Brookhaven at this time, we are including two surface conditions, one being mill finish and the other a pickled surface. Pickling is done for two reasons, one is that it will reflect (to some degree at least) the condition of tubing that may exist after chemical cleaning or after decontamination of a steam generator. Also it is known that pickling does give some acceleration to SCC and therefore reduces the time of our tests. The effect of these surface conditions on the curves previously discussed is being determined quantitatively.

\section{Metallurgical condition:}

a. Material is tested in three conditions.

The first is very susceptible production material in the form of tubing, the second is also in the form of tubing but somewhat less susceptible, and the third is tubing in the condition now used; that is, after heating at 
$700^{\circ} \mathrm{C}$ for 15 to 20 hours. The latter is supposed to yield highly resistant material. The purpose of selecting at least two production heats is to ensure that our observations of quantitative relationships between time to failure and temperature or stress are valid, and to determine the effect of variables (e.g. composition) associated with different heats of Inconel 600 nuclear grade tubing.

If parallel curves are not obtained, then we will have to explain why they are not, and how to allow for any different mechanism that may operate in different heats. Such provision can easily be included in the empirical data base.

\section{b. Structure.}

The metallurgical structure of the various pieces that we are testing is being determined for background information. The reason for this is to build up information for future use if we can determine common factors in the structure and the stress corrosion response of different heats of Inconel 600. At this time, structure cannot be used to predict performance, but may become a guide if sufficient correlation with SCC can be achieved.

\section{c. Heat treatment.}

The processing of Inconel 600 obviously is very important in determining its response to SCC in high temperature water. We are consequently developing information on the effect of heat treatment on previously cold worked inconel tubing and plate material. This is being done in steps of $20^{\circ} \mathrm{F}$ or $30^{\circ} \mathrm{F}$ in the range $1600^{\circ} \mathrm{F}-1900^{\circ} \mathrm{F}$ and exposure times in the furnace of a few minutes only, representing the conditions equivalent to what is expected in a steel mill. The results of this effort are two-fold: one is to define ways of regenerating susceptible material for future work (at will); the other is to enable us in the future to know when mill production procedures are likely to render the product susceptible to SCC. With such knowledge, we may be able to determine without any laboratory tests whether a material would be susceptible to SCC in service or not.

In examining heat treatment, we propose in future to use only the slow strain rate test, because it is considerably quicker than the U-bend test. The latter so far has not been very fruitful in examining effects of processing variables because it is too slow. The constant strain rate tests will be done at about $3 \times 10^{-7} \mathrm{sec}^{-1}$ strain rate and only in water at $365^{\circ} \mathrm{C}$ without any additions.

\section{d. Cold Work.}

Experience to date has indicated a very definite effect of cold work in rendering material more susceptible to SCC in high temperature water. In order to study this phenomenon more quantitatively, we use four levels of cold work. These experiments include $U$-bends and slow strain rate experiments. The cold work levels are: 1. no cold work; 2. tubing that is split, flattened, and rolled only $1 \mathrm{mil}$; 3. tubing flattened and rolled 5 to 7 mils; 4 . $40 \%$ cold worked material. The degree of strain associated with each of these found in being determined. 


\section{e. Carbon levels.}

Tests that have already been run indicate the possibility that carbon affects the activation energy of crack initiation in U-bends tested in constant deflection. Our additional testing at the lower temperatures is being carried out very carefully in order to ascertain the specific influence of carbon on the basic curves that are being developed. The range of carbon in the production tubing available at Brookhaven at this time is $0.01 \%$ to $0.08 \%$. These levels are practical and it is felt that they cover a wide enough range for our present purposes.

\section{Environmental Variables:}

a. Pure water only:

This is being done to establish a background for both the constant deflection, constant stress, and the constant strain rate tests.

\section{b. Primary water:}

In the first instance, simulated primary water is used in average concentrations of $B$ and $L i$, and at a pH around 6 . Initial results, as shown in the next section, indicate that there is no significant difference between results in primary water and water without the primary ingredients. In order to evaluate solutions that may exist in crevices, the pH of the primary water test will be dropped to 3 , so as to allow for changes that may occur in occluded cells when impurity anions are present. The tests under these conditions include slow strain rates as well as the U-bends, and at $365^{\circ} \mathrm{C}$ and $345^{\circ} \mathrm{C}$. Results will be sufficient to establish the similarity between the slopes of these curves and those obtained previously in pure water. Of course, the constant $k$ in Arrhenius equation will also be established by these tests. Two heats of material are used including a highly susceptible heat and one somewhat less susceptible to SCC.

\section{c. Secondary water with AVT ingredients:}

This is used at $345^{\circ} \mathrm{C}$ as well as at a somewhat lower temperature. The tests include slow strain rate as well as U-bends. Again, two heats of tubing are used for the slow strain tests: however. the aim of this test is the same as in the primary test just mentioned. Many heats of varying susceptibility will be used in the U-bend tests to correlate the effects of the different environments.

d. Phosphate additions:

Two levels of phosphate will be used: $10 \mathrm{ppm}$ and $100 \mathrm{ppm}$. Aqain. two heats of Inconel 600 will be used in the slow strain test and several heats in $\mathrm{U}$-bend tests. Two temperatures, that is $365^{\circ} \mathrm{C}$ and $345^{\circ} \mathrm{C}$ will be used. In these tests, the ratio of sodium to phosphate will be approximatelv 2.3 . 
e. Impurity additions.

Small amounts of chloride and sulfate will be added separately to pure water tests. Only a slow strain rate at about $10^{-7} \mathrm{sec}^{-1}$ will be used. This will ascertain the accelerating effect of chloride and sulfate ions which are the two most common impurity ingredients in the secondary side. Temperatures will be $365^{\circ} \mathrm{C}$ and $345^{\circ} \mathrm{C}$.

4. Other Test Variables:

a. Stress or strain levels:

The MTS unit and dead-weight loading are used to determine the effect of various stress levels on at least two heats of Inconel 600 at a temperature of $365^{\circ} \mathrm{C}$. The environments include primarily pure water and primary water, and 2 points for comparison will be included for secondary water. i.e., $345^{\circ} \mathrm{C}$ and $325^{\circ} \mathrm{C}$. This should be sufficient to establish the slopes of the curves in the log-log plot. Additionally, the level of strain present in the complex pattern formed in U-bend specimens will be measured using photoelastic techniques or grid measurements. Much of this work has already been completed.

b. Strain rate:

Strain rate is examined in order to establish the range of strain rate that does not affect the crack velocity as determined experimentally. This range needs to be established at each test temperature for the material being studied. Why this is a range that produces SCC will also be addressed; An acceptable strain rate range appears to be $10^{-8} \mathrm{sec}^{-1}$ to $10^{-7} \mathrm{sec}^{-1}$ with the slower rates necessary to produce cracking at the lowest test temperature. Also included in the slow strain rate experiments are the environmental variables as outlined above. In addition to these, we are carrying out experiments that will enable us to distinguish within the slow strain rate tests the periods of crack initiation and crack propagation. This is essential in order to establish true crack velocities and true heats of activation for the crack induction periods. These calculations will also be used for other tests which are aimed only at determining crack initiation activation energies. The latter refers to the constant deflection and constant load tests where the crack lengths will be determined so as to enable a correction for propagation times based on the slow strain rate data.

\section{c. Cyclic tests.}

In the cyclic tests, it is first necessary to establish more results. Basically, two loads will be applied as the constant background. One of these loads will be just below the yield point, and the other just above the yield point. 
Two amplitudes and two frequencies (minimum). will be used in addition to the two background loads. These will then establish the effect of amplitude and the effect of frequency on SCC response. A susceptible heat of tubing will be used as tensile specimens for this purpose. Interpretation of these data is expected to yield a mechanism which is similar to that of the slow strain rate tests. If this anticipation is correct, then the cyclic tests can be simply interpreted according to the same creep assumptions as are made for the slow strain rate tests, and will greatly simplify the model that we use or making allowance in practice for cyclic operational stresses on steam generator tubing.

\section{F. Experimental Details}

1. Materials

The material procured for this program included ingot, plate and tubing having chemical compositions within those specified for Inconel Alloy 600 . Table 1 details the chemical composition and mechanical properties of these 20 heats of material. Carbon contents range from $0.01 \%$ to $0.08 \%$. $\mathrm{N}_{2}$ content of some heats are listed in table 2. Manufacturers consider their tube processing methods proprietary information, therefore, classification of the tubing material is as follows:

a. Heats \#2, \#10, \#11 are nuclear grade production tubing manufactured using procedures similar to those used for steam generator tubing currently in service.

b. Heats \#4 and \#5 are low carbon (.01\%) materials which would possibly not be considered for current production requirements, since insufficient amounts of carbon may be in solution to provide adequate grain boundary precipitation during sensitization. However, they were produced in the same way as regular nuclear grade tubing.

c. Heats \#6 and \#12 are cold worked materials used for investigating the effect of heat treatment on producing susceptible structures.

d. Heats \#14, \#15, \#16 \& \#19 are typical of current production methods used by some manufactures. The final heat treatment for this material (20 hours at $700^{\circ} \mathrm{C}$ ) produces a semi-continuous precipitate of chromium carbide in the grain boundaries and allows chromium rediffusion into the denuded zones adjacent to the grain boundaries. This heat treatment has been shown to provide a structure with a greater resistance to intergranular stress corrosion cracking (IGSCC) in high purity water and caustic environments.

e. Heats \#17, \#18 and \#20 are materials typical of current production method but were removed from the processing line just prior to the $700^{\circ} \mathrm{C} / 20 \mathrm{hr}$. "thermal treatment."

Alternate materials to be investigated in this program include Alloy 690 , Japanese Al loy SR3 and Alloy 800. 


\section{Specimen Preparation}

Ingot and plate stock were given a series of hot or cold rollings and heat treatments in an attempt to produce a susceptible structure. These procedures are detailed in table 3 and table 4. Specimens were machined from these materials to $8.9 \mathrm{~cm} \times 1.3 \mathrm{~cm} \times .38 \mathrm{~cm}\left(3.5^{\prime \prime} \times .5^{\prime \prime} \times .150^{\prime \prime}\right)$ strips, ground to a 35 micro inch finish and then some were subjected to additional heat treatments in $\mathrm{H}_{2}$ or pickled before bending. Pickling specifications are given in table 5. Specimens were bent into a U-shape using a fixture with a $1.9 \mathrm{~cm}$ (.75.) dia. mandrel and the legs of the specimen were then fixed with a bolt so that a distance of $1.9 \mathrm{~cm}\left(.75^{\prime \prime}\right)$ was maintained.

Tube type U-bend specimens were fabricated from pieces of tubing that was split on its longitudinal axis. Pickling and heat treatments given to the cold worked tubing prior to bending are detailed in table 6 . The specimens were formed on a modified tubing bender to produce a U-bend with the original inside surface of the tubing in tension and a $1.3 \mathrm{~cm}\left(0.5^{\prime \prime}\right)$ inside radius of bend.

C-ring specimens prepared from tubing were expanded to provide a tension of $95 \%$ Y.S. or $110 \%$ Y.S. on the inside surface of the tubing.

Tensile specimens for constant extension rate tests and constant stress tests were produced by splitting the tubing lenthwise and then carefully. rolling into flat strips to produce specimens with a minimum amount of cold working. The rolling process usually resulted in a $.025 \mathrm{~mm}$ to $.05 \mathrm{~mm}$ (1 to 2 mil) reduction in wall thickness which correspond to $1 \%$ - 3\% cold reduction. Tensile specimens were then machined in accordance with ASTM specification A370 and had a $.635 \mathrm{~cm} \times 2.54 \mathrm{~cm}\left(.25^{\prime \prime} \times 1\right.$ ") gauge section. The faces corresponding to the inside and outside surface of the tubing were not machined or polished. Dual ligament tensile samples were prepared to provide a specimen without any additional cold working for comparision with the plate type specimens.

Prior to testing all specimens were ultrasonically cleaned in a detergent solution then rinsed with water and methanol. Pickled specimens were given successive rinsing in D.I. water in an ultrasonic both unt il no change in the conductance of the rinse water was noted.

\section{Test Environment}

Tests were conducted in one or two gallon pressure vessels fabricated from 3165S or Inconel Alloy 600. These vessels containing support apparatus for. U-bends and tensile specimens were cleaned by exposure to $365^{\circ} \mathrm{C}$ pure $\mathrm{H}_{2} \mathrm{O}$ for 24 hour periods. A conductance of $\leq 5 \mu \mathrm{S}$ for the water removed at the end of the test was the critieria used for determining cleanliness.

Distilled deionized water, having a conductance of $\angle 5 \mu S$ was used for all pure water tests and for preparing simulated primary or secondary environments. Oxygen removal was achieved by an initial 5 min. evacuation of the filled vessel followed by five pressure - vent cycles with $3.4 \mathrm{MPa}$ (500 psig) of high purity $\mathrm{N}_{2}$. The vessel was again evacuated and $15 \%$ of its volume steamed off when the system reached $110^{\circ} \mathrm{C}$. 0xygen concentration after this procedure was determined to be in the 0 to $5 \mathrm{ppb}$ range. 
Primary water exposures of U-bend specimens were conducted in a circulating autoclave system. The test solution, typical of primary side $\mathrm{H}_{2} \mathrm{O}$, contained $10^{-4} \mathrm{M} \mathrm{LiOH}$ and $650 \mathrm{ppm} \mathrm{B}$ as boric acid. A $\mathrm{H}_{2}$ overpressure was applied to the make-up water to produce a concentration of $35 \mathrm{STP} \mathrm{cc} / \mathrm{Kg}$. $0 x y-$ gen removal was achieved by continually sparging the water reservoir. Refreshment of the test solution was maintained at $0.1 \mathrm{gpm}$. Constant extension rate tests were conducted in static systems with enough additional $\mathrm{H}_{2} \mathrm{O}$ added to allow steaming and still maintain the specified chemical concentration.

Simulated secondary water, corresponding to the currently used all volatile treatment (AVT), was prepared by first degassing the $\mathrm{H}_{2} \mathrm{O}$ filled vessel then cooling and injecting morpholine and hydrazine thru a rubber serum stopple into an evacuated port. Decomposition of both of these additives are expected at the highest test temperature $\left(345^{\circ} \mathrm{C}\right)$ used with this environment. Hydrazine will decompose rapidly at this temperature, however, the rapid gettering action of this additive should have completed its task in removing the residual $\mathrm{O}_{2}$ in the time required to reach test temperature. Decomposition of morpholine requires a much longer time and the $\mathrm{pH}$ of the test solution after a two week period still remained slightly basic. Additional information regarding the decomposition rate of these additives, at this temperature, is being sought by liquid and vapor phase sampling during the test period.

G. Experimental Determination of Crack Initiation in Statically Stressed

1. Constant Deflection Tests

Replicate $U$-bend and $\mathrm{C}$-ring specimens were exposed to pure deoxygenated water at test temperatures of $365^{\circ} \mathrm{C}, 345^{\circ} \mathrm{C}, 325^{\circ} \mathrm{C}$ and $290^{\circ} \mathrm{C}$. These tests included specimens prepa:ed from heats \#1 thru \#13. Those heats identified by \#14 thru \#20 were received later in the program and were not included in these tests. Specimens exposed at the three highest temperatures were examined with a $30 \mathrm{X}$ binocular microscope at two week intervals and those at $290^{\circ} \mathrm{C}$ were inspected every six weeks. Pure water tests at $365^{\circ} \mathrm{C}$ and $345^{\circ} \mathrm{C}$ were terminated after 36 weeks and exposures at the two lower temperatures are continuing.

Primary water exposures at $365^{\circ} \mathrm{C}$ contained U-bend specimens fabricated from material found to be susceptible to SCC in the pure water tests and also the material received later in the program (heats \#14 thru \#20). The primary water test at $365^{\circ} \mathrm{C}$ was terminated after 24 weeks.

AVT tests at $345^{\circ} \mathrm{C}$ were conducted with the same series of materials exposed in the primary water tests. Termination of the AVT test is also scheduled for 24 weeks.

$325^{\circ} \mathrm{C}$

New tests are now in progress in primary water at $345^{\circ} \mathrm{C}$ and in AVT at 


\section{a. Test Resuits}

U-bend specimens prepared from $\mathrm{plate}$ and ingot were intended to provide a very susceptible material which could be compared with the presumably less susceptible production tubing. These specimens were removed from the pure $\mathrm{H}_{2} \mathrm{O}$ test at $365^{\circ} \mathrm{C}$ after 14 weeks to provide space for additional tube $\mathrm{U}$-bend specimens when it was found that the production material exhibited SCC after very short exposure periods. None of the plate type specimens showed any SCC during this time. It is difficult to establish what differences exist between the laboratory heat treatments or rolling and mill practice, since tube manufactures follow proprietary procedures. However, it seems quite certain that there is a strong connection between the SCC of Inconel 600 in pure high temperature water (and in primary water), and processing history. New tests are done in slow strain apparatus.

Pure water tests at all four test temperatures $\left(365^{\circ} \mathrm{C}, 345^{\circ} \mathrm{C}, 325^{\circ} \mathrm{C}\right.$ and $290^{\circ} \mathrm{C}$ ) contained C-ring specimens machined from the tubing stock. With the exception of those prepared from cold worked material, none of these specimens which were stressed to $95 \%$ or $110 \%$ Y.S. failed during the tests.

Specimens fabricated from 5 heats of regular production tubing have failed by IGSCC in pure deaerated water tests at $365^{\circ} \mathrm{C}$ and $345^{\circ} \mathrm{C}$ and two heats failed at $325^{\circ} \mathrm{C}$. The most susceptible heats showed SCC in the first two week exposure period. Tables 7 and $7 \mathrm{~A}$ give the results of these tests and average failure times. Replicate specimens agreed reasonably well, but there are some exceptions typical of the scatter usually found in this type of test.

Figures 1,2 , and 3 show the time to failure as a function of temperature for these materials in pure water and in simulated primary and secondary solutions. A trend toward higher activation energies for the higher carbon materials is graphically demonstrated in figure 4 when the failure times at $365^{\circ} \mathrm{C}$ are given a single reference point. Additional data are needed at the lower test temperature before a significant degree of confidence can be applied to this observation.

Micrographs of two susceptible heats of material are shown in Figure 5 and two non-susceptible heats in Figure 6 . These specimens which were electrolytically etched in nital to show the grain boundaries and in $\mathrm{H}_{3} \mathrm{PO}_{4}$ to outline the carbide precipitates, do not demonstrate any differences which may account for:their SCC susceptibility. None of the structures have the grain boundaries outlined with the carbide precipitates that are usually associated with a non-susceptible structure. Micrographs of new production tubing (without thermal treatment) are shown in figure 7. Although the grain boundaries appear to be well outlined with carbide precipitates, these materials did crack in primary water tests and AVT tests which will be discussed later in this report. Therefore, it appears that an accurate prediction of material performance cannot be based on microstructural analysis alone. 
Pickling appears to have a somewhat erratic effect at the highest test temperature, however, most of the susceptible heats show that this treatment does have an adverse effect. The low carbon materials (heats \#4 and \#5) cracked mostly when unpickled at $365^{\circ} \mathrm{C}$, but mostly in the pickled condition at $345^{\circ} \mathrm{C}$. Heat $\# 2$ appears to be indifferent to pickling, whereas heat \#10 cracked only in the pickled condition. and the time to failure for heat \#11 was decreased by pickling. The recently received heats \#17 \& 18 which were exposed only to primary water and AVT environments cracked only when pickled although heat \#20 fabricated with the same production methods cracked in either condition with pickled specimens failing somewhat sooner.

Comparison of failure times for specimens exposed to pure water, primary water or AVT are shown in Figs. 1, 2, and 3. For some of the materials, failure occurred sooner in the AVT or primary $\mathrm{H}_{2} \mathrm{O}$ than in pure water. This was not true for all the susceptible heats and additional data are needed to determine a definite relationship. Primary water exposures at $345^{\circ} \mathrm{C}$ and AVT tests at $325^{\circ} \mathrm{C}$ are now underway.

Plate type U-bend specimens machined to like thickness and having similar physical properties produce specimens with equal stress levels, however, significant differences in stress level are expected for the reverse tube U-bend specimens. Variation in outside diameter and wall thickness in production tubing affect the stress levels in these specimens which are all formed on the same fixture. The thin walled tubes flare more when the specimens are bent and this flaring produces a larger hoop stress component, which counteracts the lowering of stress due to the reduced thickness. The strain levels and patterns produced in the various materials are currently being studied by a photoelastic method. These strains will be correlated with the stress levels and failure times.

\section{Constant Stress Tests}

Preliminary constant stress tests used a bolt loaded pull rod to apply stress to the specimen. This system produced SCC in some of the specimens tested in rather short times. However, room temperature fluctuations caused expansion and contraction of the pull rod and resulted in a cyclic component on the load. Therefore, the results from these tests are questionable.

An MTS system and a dead weight loaded level system which tests three specimens simultaneously are now being used for these tests. Three specimens from a single heat of material are loaded to different stress levels in the dead weight apparatus to provide identical conditions with the exception of the stress. Both of these tests indicate precise time to failure and the MTS system also records the strain during the test.

\section{a. Constant Stress Test Results}

Plate type tensile specimens were exposed to a constant load in pure deaerated water at $365^{\circ} \mathrm{C}$. The preliminary results shown in figure 8 are for heat \#4 tested in a pure water environment at $365^{\circ} \mathrm{C}$ with the controlled load applied by an MTS system. Since significantly different yield strengths 
were exhibited by these specimens as a result of varying degrees of cold work, it was appropriate to plot failure time against stress beyond yield rather than the total applied stress. These initial results tentatively indicate that the failure time is inversely proportional to $\sigma^{3}$.

\section{H. Experimental Determination of Crack Propagation in Dynamically Stressed Specimens}

\section{Constant Extension Rate Tests (CERT)}

The CERT apparatus was previously described in the June 1979 report mentioned earlier. Three CERT systems are presently being used for this program. Two of the systems test single specimens and the third system, which strains four specimens in series, is used as a rapid sorting test to determine the susceptibility of the thermally treated Inconel or alternate materials.

Plate type tensile specimens are being used for most of the CERT tests since the cold work in these samples produces results in a shorter time. Additional tests are being conducted to correlate these results with "as received" material and material with a greater amount of cold work.

The constant extension rate test simulates the conditions experienced by steam generator tubes that are undergoing active denting. Slow straining may also be an important factor in promoting the SCC of U-bend, constant stress or cyclic load specimens where the material is creeping due to the sustained load. Constant extension rate tests greatly reduces the time necessary to initiate cracking such as in U-bend tests and ultimately results in specimen fracture either by SCC, ductile failure or a combination of these.

\section{a. CERT Results}

As mentioned previously, plate type tensile specimens fabricated from tubing contained $1 \%$ to $3 \%$ of cold rolling after flattening. This amount of cold reduction was beneficial in producing rapid results, although it has been shown that cold working is not necessary to produce SCC and additional work is in progress to expand our data on this effect.

10-6 $\mathrm{sec}^{-1}$ Intergranular SCC has been produced using a strain rate range of to $10^{-8} \mathrm{sec}^{-1}$ with the slower rates required to provide a substantial crack depth at the lower test temperatures. The $\log \dot{\varepsilon}$ plotted against $\log$ crack velocity in figure 9 appears to be linear in the range tested. Additional tests will be conducted to determine the limits.

Specimens fractured in CERT were examined by SEM to determine the fracture mode even though it was apparent from microscopic examination and the presence of secondary cracks that the failures were intergranular SCC. The 
cracking originated in the faces corresponding to the original tube surfaces rather than on the machined sides. They were not, however, confined to a particular side; the inside surface of the tubing appears to be as susceptible as the outside.

It is necessary to define the stress or strain level at which crack initiation occurs before crack velocities can be calculated. Several tests were stopped at various strain levels and close examination showed that SCC was not always present. Since additional tests are scheduled to determine the initiation time, but not completed, the yield point of the material was chosen as a reference. This obviously will be corrected when a clear separation between initiation and propagation is established. Crack velocities are now calculated by dividing the maximum intergranular crack depth by the straining time from yield to failure.

A number of tests were conducted on heat \#4 to determine the effect of temperature, environment, strain rate, aging and cold work. Figure 10 shows the crack velocities produced with these conditions as a function of temperature. Data from pure deaerated water tests at $365^{\circ} \mathrm{C}, 345^{\circ} \mathrm{C}, 325^{\circ} \mathrm{C}$ and $290^{\circ} \mathrm{C}$ produce reasonably good straight line results. Two of the pure water results at $325^{\circ} \mathrm{C}$ show that the crack velocities of specimens tested at a $\dot{\varepsilon}$ of $2.9 \times 10^{-7} \mathrm{sec}^{-1}$ or $3.9 \times 10^{-8} \mathrm{sec}^{-1}$ agree very well. The other point shown at $325^{\circ} \mathrm{C}$ is for a specimen which was aged for 18 weeks in pure water at $365^{\circ} \mathrm{C}$ before testing. It is apparent that the oxide present after this aging as well as any low temperature sensitization which may have taken place had no discernable affect on the crack velocity.

Tests with heat $\# 4$ at $345^{\circ} \mathrm{C}$ in addition to pure water in a stainless steel vessel included tests in AVT, primary water, and pure water in a system constructed entirely of Inconel 600. Figure 9 shows that the results from these three tests also agree very well.

Figure 10 also gives a comparison of the CERT results for heat \#2, \#4 and \#5. These parallel results are encouraging since the activation energy appears 'to be the same for the three heats tested. It is evident from these results that a single high temperature test may be used to predict crack velocities at operating temperatures.

Several materials that were found to be non-susceptible to SCC in high temperature pure water when tested as U-bends were strained in the CERT apparatus. The slow straining did not produce any SCC in these materials or unpickled materials which cracked only in the pickled condition in the U-bend tests.

\section{Cyclic Load Test}

An MTS closed-loop, electronically controlled, hydraulic system with an overhead actuator is used to apply a programmed load cycle to a tensile test piece in addition to a constant load. The cycles are tension-tension with a pre-selected spread. Initial tests have been in pure water at $365^{\circ} \mathrm{C}$. 
Load and strain are continuously recorded throughout the test.

\section{a. Cyclic Load Test Results}

The results from tension-tension type cyclic load tests are given in table 8. A load cycling between $110 \%$ Y.S. to $130 \%$ Y.S. was applied in a sinusoidal wave form at frequencies of $10^{-1}, 10^{-2}$ and $10^{-3} \mathrm{~Hz}$. The yield strength of each plate type specimen used was determined at the beginning of the test and was defined as the point at which the strain time curve departed from linearity under a constant rate of loading. These conditions produced failure in each condition after practically equal exposure times and approximately equal elongation even though the number of cycles varied by a factor of 10 between each test. These results indicate that the act of plastic deformation is the most important factor in producing the cracks. Data are not yet available to determine the change in strain rate over the life of these tests; however, if the specimen elongation is divided by the time of increasing stress cycle the strain rates for the first three tests listed in table 8 is $3.0 \times 10^{-7} \mathrm{sec}^{-1}$. This is the rate used for producing SCC in CERT tests conducted at this temperature. The test conducted at a frequency of $10 \mathrm{~Hz}$ produced fine intergranular cracks which did not propagate to failure at a strain rate of $5.6 \times 10^{-8} \mathrm{sec}^{-1}$. A load range of $100 \%$ Y.S. to $140 \%$ Y.S. as shown in the fifth test listed also produced deep intergranular SCC with an overali average strain rate of $1.0 \times 10^{-7} \mathrm{sec}^{-1}$. Additional cyclic testing is in progress with the strain monitored throughout the test and crack velocities will be compared to specimens tested in CERT. Measurement of strain with time during these tests will provide information on crack initiation by a change-in slope.

\section{Discussion}

The predictive model based on laboratory results will, after completion, enable one to determine quantitatively the life expectancy of steam generator tubing that is in service, or of candidate materials. The best approach in both instances would involve a few accelerated tests to determine both crack initiation and crack propagation which may be experienced under normal or fault conditions. This could easily be done for candidate materials but may not be practical for in-service material unless Archive samples were available, otherwise tube sections could be removed for hot lab testing. In the event that neither of these options were available, estimates could be made from conditions which may have produced isCC in comparison tubes, or, conservatively, data from the most susceptible heats

Laboratory results indicate that for at least two heats of material (heat \#5 and heat \#4) a single mechanism seems to govern the crack initiation stage. A semi-log Arrhenius curve for this material (Fig. l) gives a straight line for the specimens which failed at the three highest test temperatures. It is expected that all heats with moderate carbon levels will exhibit this straight line relationship and permit crack initiation at operating temperatures to be established by a more rapid high temperature test and these results extrapolate back to the service conditions. The other low carbon material (heat \#4) also produced specimen failure after 51 weeks at $325^{\circ} \mathrm{C}$. This is approximately the 
failure time predicted given the $T_{f}$ at $365^{\circ} \mathrm{C}$, if it is assumed that the activation energy for both of the low carbon materials are similar. Due to the erratic effect of pickling on these low carbon alloys exposed at high temperature we do not have specimen failures at similar test conditions for heat \#4 at all temperatures so that one may have a three temperature comparison.

Figure 4 shows that a higher activation energy, hence a longer time to failure at the lower temperature is expected for the three susceptible materials (heats \#2, \#10 and \#11) which have carbon contents of .02\%, .03\% and $.05 \%$. As expected, none of these heats have cracked after 52 weeks exposure to pure $\mathrm{H}_{2} \mathrm{O}$ at $325^{\circ} \mathrm{C}$. This test will continue until data are obtained for these materials which for the highest carbon material may require two years exposure.

Several other factors that need to be considered in determining crack initiation are the stress levels of the different specimens and whether this stress is maintained or if relaxation may occur after prolonged exposure to high temperature environments. Preliminary results using a photoelastic strain analysis technique indicate that localized plastic strains of $20 \%$ or greater may be experienced when the U-bend is formed. This is considerably higher than the levels which produced rapid failures in constant stress tests. Specimens from heat \#4 failed in constant stress after 6 days or less whereas U-bend specimens froll this heat required 11 weeks to produce failures. In the U-bends, creep occurs during the time between making the specimen and placing it in test and heating the water. In the constant load test most of the creep occurs during the exposure period.

The stress level dependency of crack initiation is being studied by the constant stress test. The tests conducted on heat \#4 (Fig. 8) indicate that stress above yield plotted against the time to failure produces a straight line relationship with $T_{f} \alpha \sigma^{-3}$. The strain monitored throughout the test also indicates when fracture is occurring. This measurement indicates that the crack velocities are approximately a factor of' 10 higher than those determined for the constant extension rate tests. Only if one assumed that cracking initiated at the time of loading could a crack velocity be calculated which would be comparable to those produced in the CERT test. If this were indeed the case, a gradual change in displacement would be expected. These results suggest that the crack initiation in the slow strain rate tests does indeed occur well beyond yield.

Crack propagation velocities determined by the constant extension rate test can be used to predict the service life of tubes which may be experiencing continual deformation by processes such as denting. Fig. 10 showed that the crack velocities for three different materials formed a family of parallel curves which were not affected by the various service related environments. Excellent agreement exists between the data points at the lower temperatures, however, the scatter at $365^{\circ} \mathrm{C}$ requires that additional tests be conducted at this temperature to determine if the curve is still linear in this region. As previously mentioned, tests are also underway to determine the strain or stress level at which initiation takes place and also the effects of cold working. 
TABLE 1

Mechanical Properties and Chemical

Composition of Test Materials

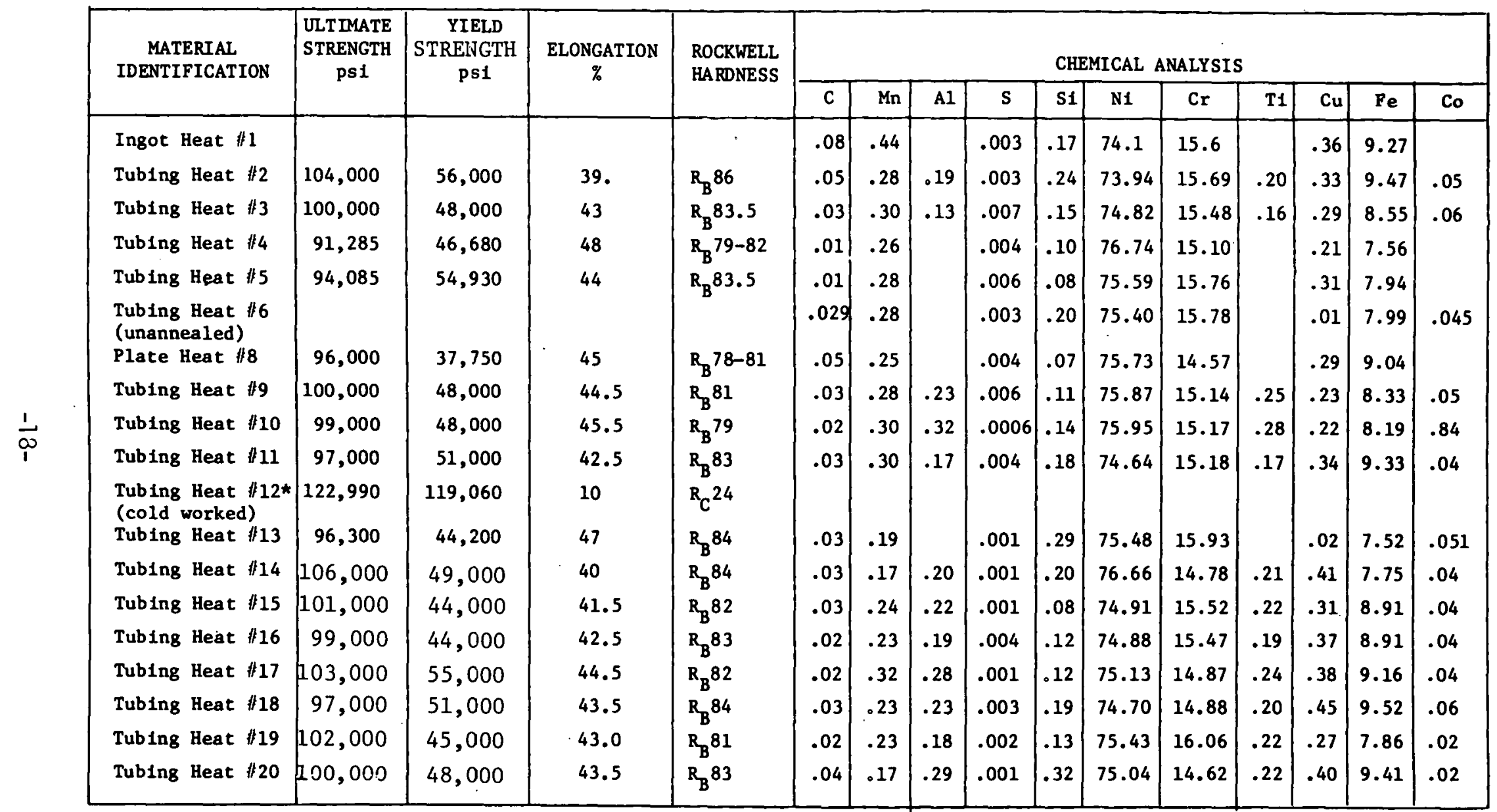

*Heat \#5 with $40 \%$ cold work 
TABLE 2 Nitrogen Content and Average Failure Times of Incone 1600

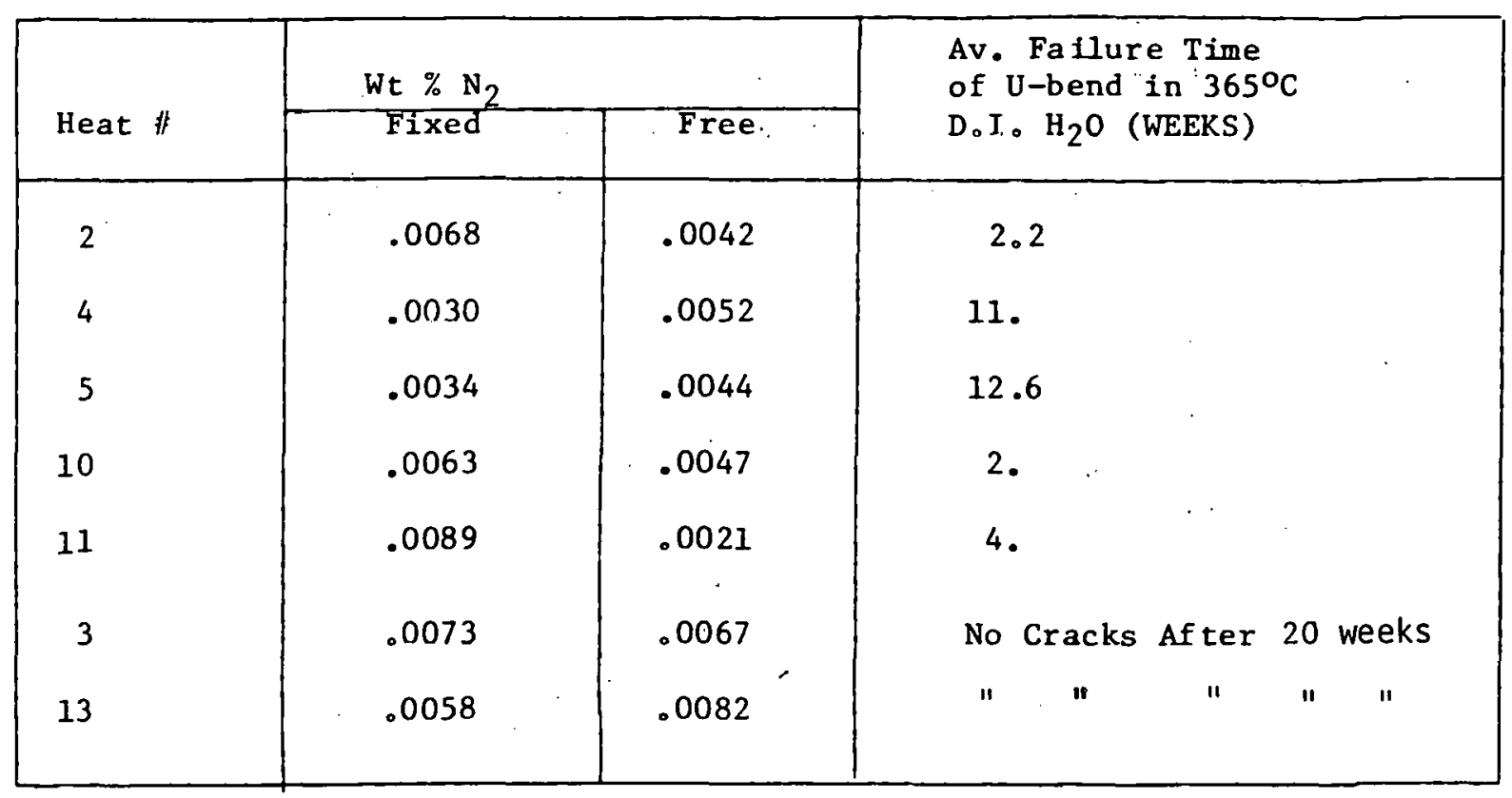


TABLE 3

SPECIMENS FABRICATED FROM INGOT AND EXPOSED O $365^{\circ} \mathrm{C}$

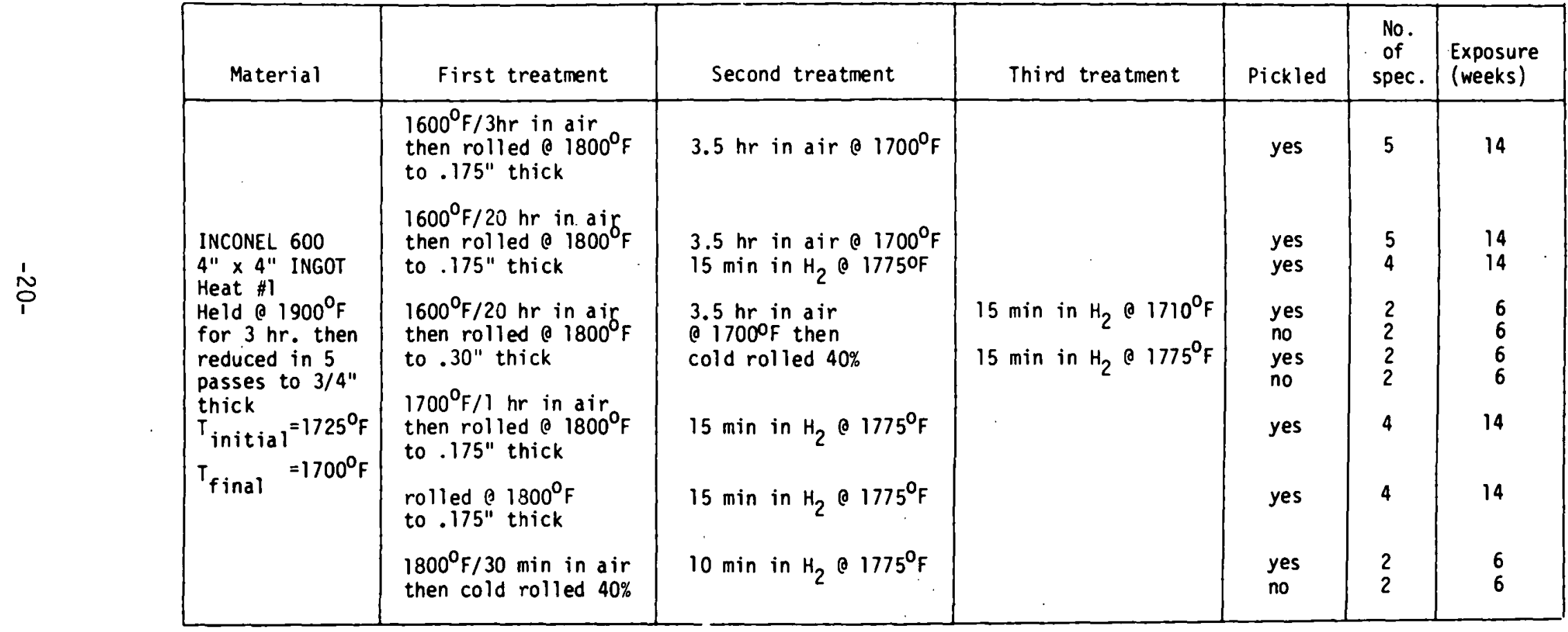


TABLE 4

SPECIMENS FABRICATED FROM PLATE AND EXPOSED \& $365^{\circ} \mathrm{C}$

\begin{tabular}{|c|c|c|c|c|c|}
\hline$=\quad$ Material & First treatment & Second treatment & Pickled & $\begin{array}{l}\text { No. of } \\
\text { specimens }\end{array}$ & $\begin{array}{l}\text { Exposure } \\
\text { (weeks) }\end{array}$ \\
\hline 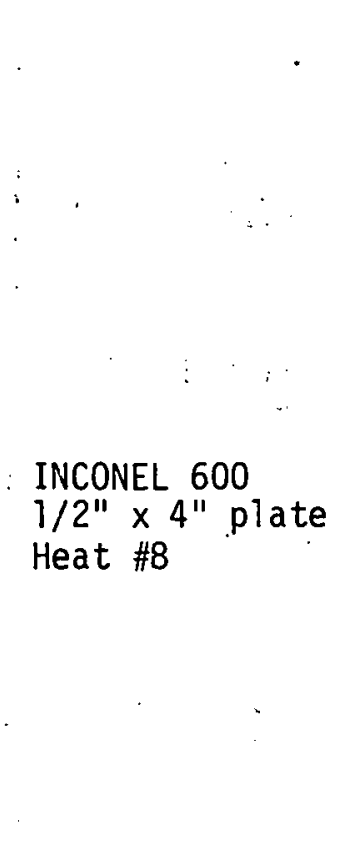 & $\begin{array}{l}1775^{\circ} \mathrm{F} / 15 \text { min in air } \\
\text { then rol led o } 1800^{\circ} \mathrm{F} \\
\text { to . 30" thick. } \\
\text { Cold rolled } 40 \% \\
\qquad .\end{array}$ & $\begin{array}{l}10 \mathrm{~min} \text { in } \mathrm{H}_{2} @ 1700^{\circ} \mathrm{F} \\
10 \mathrm{~min} \text { in } \mathrm{H}_{2} @ 1735^{\circ} \mathrm{F} \\
10 \mathrm{~min} \text { in } \mathrm{H}_{2} @ 1775^{\circ} \mathrm{F} \\
10 \mathrm{~min} \text { in } \mathrm{H}_{2} @ 1800^{\circ} \mathrm{F} \\
1 \mathrm{hr} \text { in air } 01680^{\circ} \mathrm{F} \\
1 \mathrm{hr} \text { in air } 01725^{\circ} \mathrm{F} \\
1 \mathrm{hr} \text { in air } 01775^{\circ} \mathrm{F}\end{array}$ & $\begin{array}{l}\text { yes } \\
\text { no } \\
\text { yes } \\
\text { no } \\
\text { yes } \\
\text { no } \\
\text { yes } \\
\text { no } \\
\\
\text { yes } \\
\text { no } \\
\text { yes } \\
\text { no } \\
\text { yes } \\
\text { no }\end{array}$ & $\begin{array}{l}2 \\
2 \\
2 \\
2 \\
2 \\
2 \\
2 \\
2\end{array}$ & $\begin{array}{l}6 \\
6 \\
6 \\
6 \\
6 \\
6 \\
6 \\
6\end{array}$ \\
\hline
\end{tabular}


Table $5 \quad \mathrm{HNO}_{3}-\mathrm{HF}$ Pickling Solution

\begin{tabular}{|l|c|}
\hline Constituents & Requirements \\
\hline $\mathrm{HNO}_{3}(\mathrm{sp} \cdot \mathrm{gr} \cdot=1.33)$ & 275 parts by volume \\
$\mathrm{HF}(40 \%)$ & 50 parts by volume \\
$\mathrm{H}_{2} \mathrm{O}$ & 65 parts by volume \\
Temperature & $122^{\circ} \mathrm{F}$ to $140^{\circ} \mathrm{F}$ \\
Time & $15 \mathrm{~min}$. \\
\hline
\end{tabular}


Table 6. Treatment of Cold Worked Tubing before Forming into U-bend Specimens

Specimen from Heat \#6 were given the following treatments then exposed to $365^{\circ} \mathrm{C}$ deaerated $\mathrm{H}_{2} \mathrm{O}$ for 24 weeks without any evidence of I.G.S.C.C.

$$
\begin{aligned}
& 15 \text { min in } \mathrm{H}_{2} \odot 1710^{\circ} \mathrm{F} \\
& 15 \text { min in } \mathrm{H}_{2} \odot 1710^{\circ} \mathrm{F}+\text { pickle } \\
& 15 \text { min in } \mathrm{H}_{2} \odot 1775^{\circ} \mathrm{F} \\
& 15 \text { min in } \mathrm{H}_{2} \odot 175^{\circ} \mathrm{F}+\text { pickle }
\end{aligned}
$$

Specimens from Heat $\# 12$ were given the following treatment then exposed to $365^{\circ} \mathrm{C}$ deaerated $\mathrm{H}_{2} \mathrm{O}$ for 22 weeks without any evidence of I.G.S.C.C.

$$
\begin{aligned}
& 10 \min \text { in } \mathrm{H}_{2} \text { @ } 1600^{\circ} \mathrm{F} \\
& \text { " " " " " + pickle } \\
& 10 \min \text { in } \mathrm{H}_{2} \text { ○ } 1625^{\circ} \mathrm{F} \\
& \text { ". " " " " + pickle } \\
& 10 \mathrm{~min} \text { in } \mathrm{H}_{2} \text { e } 1650^{\circ} \mathrm{F} \\
& \text { " " " " " " + pickle } \\
& 15 \min \text { in } \mathrm{H}_{2} \text { ○ } 1710^{\circ} \mathrm{F} \\
& \text { " ": " " " " + pickle } \\
& 15 \text { min in } \mathrm{H}_{2} \text { ○ } 1740^{\circ} \mathrm{F} \\
& \text { " " " " " + pickle } \\
& 15 \mathrm{~min} \text { in } \mathrm{H}_{2} \text { @ } 1775^{\circ} \mathrm{F} \\
& \text { " " " " " " + pickle } \\
& 15 \mathrm{~min} \text { in } \mathrm{H}_{2} \text { ○. } 1800^{\circ} \mathrm{F} \\
& \text { " " " " " pickle }
\end{aligned}
$$


Table 7 Materials Experiencing IGSCC in U-bend Tests

\begin{tabular}{|c|c|c|c|c|c|c|}
\hline $\begin{array}{l}\text { Heat } \\
\text { No. }\end{array}$ & $\begin{array}{l}\text { Specimen } \\
\text { Condition }\end{array}$ & $\begin{array}{l}\text { Test } \\
\text { Temp. } \\
\left({ }^{\circ} \mathrm{C}\right)\end{array}$ & $\begin{array}{l}\text { Environ- } \\
\text { ment }\end{array}$ & $\begin{array}{l}\text { Specimens Failed } \\
\text { Specimens Tested }\end{array}$ & $\begin{array}{l}\text { Average Time } \\
\text { to Failure } \\
\text { (Weeks) }\end{array}$ & $\begin{array}{l}\text { Exposure Time of } \\
\text { Unfailed Specimens }\end{array}$ \\
\hline \multirow[t]{8}{*}{2} & As rec'd & 365 & $\mathrm{H}_{2} \mathrm{O}$ & $3 / 4$ & 2 & 36 \\
\hline & Pickled & & $\mathrm{H}_{2} \mathrm{O}$ & $2 / 2$ & 2 & - \\
\hline & As $r e c^{\prime} \mathrm{d}$ & 345 & $\mathrm{H}_{2} \mathrm{O}$ & $2 / 2$ & 14 & - \\
\hline & Pickled & & $\mathrm{H}_{2} \mathrm{O}$ & $2 / 2$ & 16 & - \\
\hline & As $\operatorname{rec}^{\prime} \mathrm{d}$ & 325 & $\mathrm{H}_{2} \mathrm{O}$ & $0 / 2$ & - & 52 \\
\hline & Pickled & & $\mathrm{H}_{2} \mathrm{O}$ & $0 / 2$ & - & 52 \\
\hline & As $r e c^{\circ} \mathrm{d}$ & 365 & primary & $2 / 2$ & 4 & - \\
\hline & As rec'd & 345 & AVT & $2 / 2$ & 5 & - \\
\hline \multirow[t]{8}{*}{4} & As $\mathrm{rec}^{\prime} \mathrm{d}$ & $\cdot 365$ & $\mathrm{H}_{2} \mathrm{O}$ & $2 / 2$ & 11 & - \\
\hline & Pickled & & $\mathrm{H}_{2} \mathrm{O}$ & $0 / 2$ & - & 18 \\
\hline & As rec'd & 345 & $\mathrm{H}_{2} \mathrm{O}$ & $0 / 2$ & - & 36 \\
\hline & Pickled & & $\mathrm{H}_{2} \mathrm{O}$ & $2 / 2$ & 10 & - \\
\hline & As $\operatorname{rec}^{\prime} \mathrm{d}$ & 325 & $\mathrm{H}_{2} \mathrm{O}$ & $1 / 2$ & 51 & 52 \\
\hline & Pickled & & $\mathrm{H}_{2} \mathrm{O}$ & $0 / 2$ & - & 52 \\
\hline & As $r e c^{\prime} d$ & 365 & primary & $2 / 2$ & 12 & - \\
\hline & As rec'd & 345 & AVT & $2 / 2$ & 7 & - \\
\hline \multirow[t]{8}{*}{5} & As $\mathrm{rec}^{\prime} \mathrm{d}$ & 365 & $\mathrm{H}_{2} \mathrm{O}$ & $4 / 4$ & 12 & - \\
\hline & Pickled & & $\mathrm{H}_{2} \mathrm{O}$ & $1 / 4$ & 9 & 30 \\
\hline & As rec'd & 345 & $\mathrm{H}_{2} \mathrm{O}$ & $2 / 2$ & 16 & - \\
\hline & Pickled & & $\mathrm{H}_{2} \mathrm{O}$ & $2 / 2$ & 13 & - \\
\hline & As $r e c^{\prime} d$ & 325 & $\mathrm{H}_{2} \mathrm{O}$ & $0 / 2$ & - & 52 \\
\hline & Pickled & & $\mathrm{H}_{2} \mathrm{O}$ & $1 / 2$ & 29 & 52 \\
\hline & As rec'd & 365 & primary & $0 / 2$ & - & 23 \\
\hline & As rec'd & 345 & AVT & $2 / 2$ & 19 & - \\
\hline
\end{tabular}


Table 7a Materials Experiencing IGSCC in U-bend Tests

\begin{tabular}{|c|c|c|c|c|c|c|}
\hline $\begin{array}{r}\text { Heat } \\
\text { No. }\end{array}$ & $\begin{array}{l}\text { Specimen } \\
\text { Condition }\end{array}$ & $\begin{array}{l}\text { Test } \\
\text { Temp. } \\
\left({ }^{\circ} \mathrm{C}\right)\end{array}$ & $\begin{array}{l}\text { Environ- } \\
\text { ment }\end{array}$ & $\begin{array}{l}\text { Specimens Failed } \\
\text { Specimens Tested }\end{array}$ & $\begin{array}{l}\text { Average Time } \\
\text { to Failure } \\
\text { (Weeks) }\end{array}$ & $\begin{array}{l}\text { Exposure Time of } \\
\text { Unfailed Specimens }\end{array}$ \\
\hline \multirow[t]{10}{*}{10} & As rec'd & 365 & $\mathrm{H}_{2} \mathrm{O}$. & $0 / 2$ & - & 36 \\
\hline & Pickled & & $\mathrm{H}_{2} \mathrm{O}^{\circ}$ & $2 / 2$ & 2 & - \\
\hline & As rec'd & $345^{\circ}$ & $\mathrm{H}_{2} \mathrm{O}$. & $0 / 2$ & - & 36 \\
\hline & Pickled & & $\mathrm{H}_{2} \mathrm{O}$ & $2 / 2$ & 5 & - \\
\hline & As rec'd, & 325. & $\mathrm{H}_{2} \mathrm{O}$ & $0 / 2$ & - & 52 \\
\hline & Pickled & & $\mathrm{H}_{2} \mathrm{O}$ & $0 / 2$ & - & 52 \\
\hline & As rec'd & 365 & primary & $2 / 2$ & 21 & - \\
\hline & Pickled & & primary & $2 / 2$ & 1 & - \\
\hline & As rec'd & 345 & $\mathrm{AVT}$ & $.0 / 2$ & - & 12 \\
\hline & Pickled & & AVT & $2 / 2$ & 8 & - \\
\hline \multirow[t]{10}{*}{11} & As rec'd & 365 & $\mathrm{H}_{2} \mathrm{O}$ & $1 / 2$ & 13 & 34 \\
\hline & Pickled & & $\mathrm{H}_{2} \mathrm{O}$ & $2 / 2$ & 4 & - \\
\hline & As rec'd & 345 & $\mathrm{H}_{2} \mathrm{O}$ & $0 / 2$ & - & 36 \\
\hline & Pickled & & $\mathrm{H}_{2} \mathrm{O}$ & $2 / 2$ & $16^{\circ}$ & - \\
\hline & As rec'd & 325 & $\mathrm{H}_{2} \mathrm{O}$ & $0 / 2$ & - & 52 \\
\hline & Pickled & & $\mathrm{H}_{2} \mathrm{O}$ & $0 / 2$ & - & 52 \\
\hline & As rec'd & 365 & primary & $1 / 2$ & 22 & 23 \\
\hline & Pickled & & primary & $2 / 2$ & 1 & - \\
\hline & As rec'd & 345 & AVT & $0 / 2$ & - & 20 \\
\hline & Pickled & & AVT & $2 / 2$ & 11 & - \\
\hline \multirow[t]{3}{*}{17} & As rec'd & 365 & primary & $0 / 2$ & - & 23 \\
\hline & Plckled & & primary & $2 / 2$ & 14. & $\cdot-$ \\
\hline & Pickled & 345 & AVT & $1 / 2$ & 17. & 18 \\
\hline \multirow[t]{3}{*}{18} & As rec'd & 365 & primary & $0 / 2$ & - & 23 \\
\hline & Pickled & & primary & $1 / 1$ & 17 & - \\
\hline & Pickled & 345 & AVT & $2 / 2$ & 9 & - \\
\hline \multirow[t]{3}{*}{20} & As rec' $\mathrm{d}$ & 365 & primary & $2 / 2$ & 14 & - \\
\hline & Pickled & & primary & $1 / 2$ & 5 & 18 \\
\hline & P̈ickled & 345 & AVT & $0 / 2$ & - & .18 \\
\hline
\end{tabular}


Table 8 Results of Cyclic Load Tests

in D.I. $\mathrm{H}_{2} \mathrm{O}$ at $365^{\circ} \mathrm{C}$

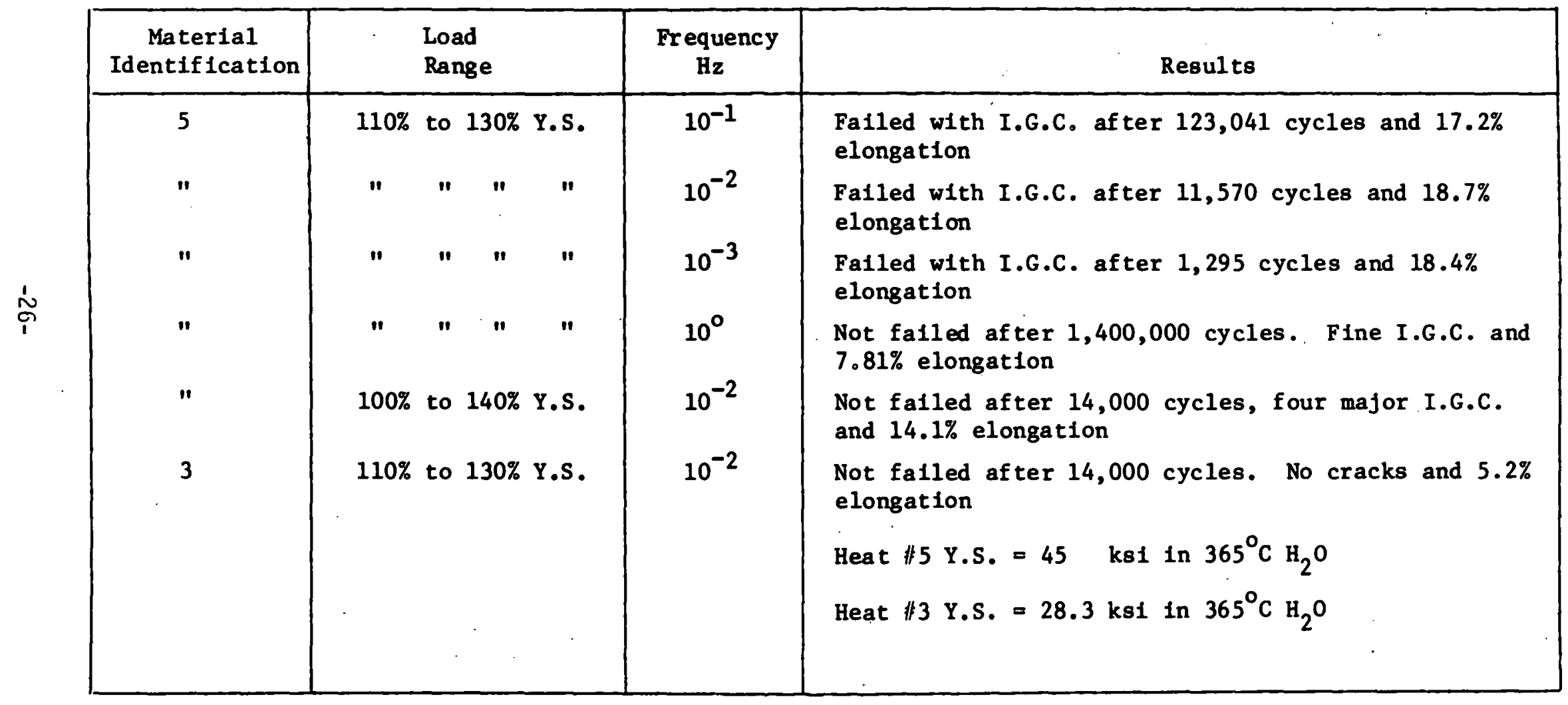




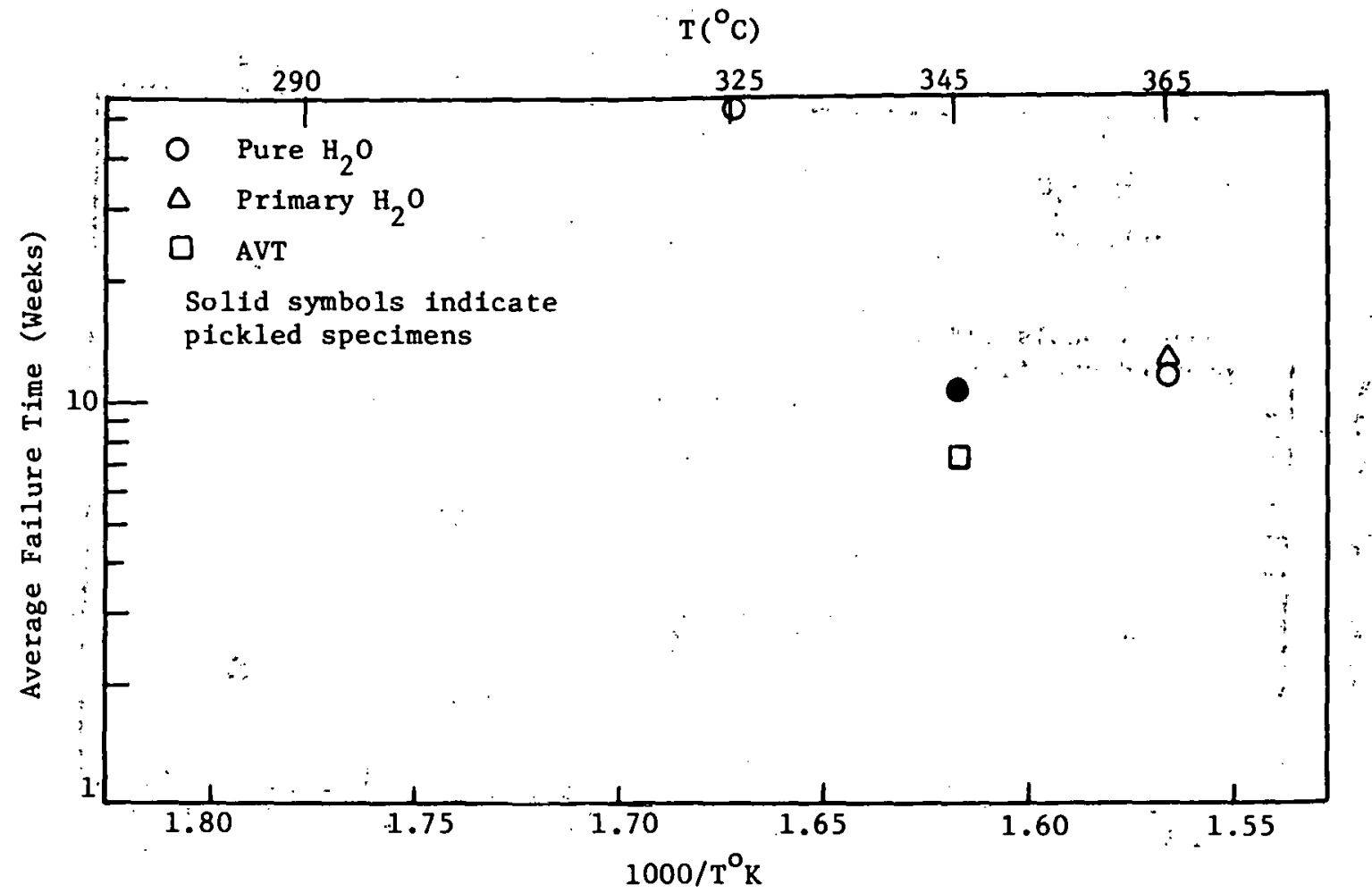

(A)

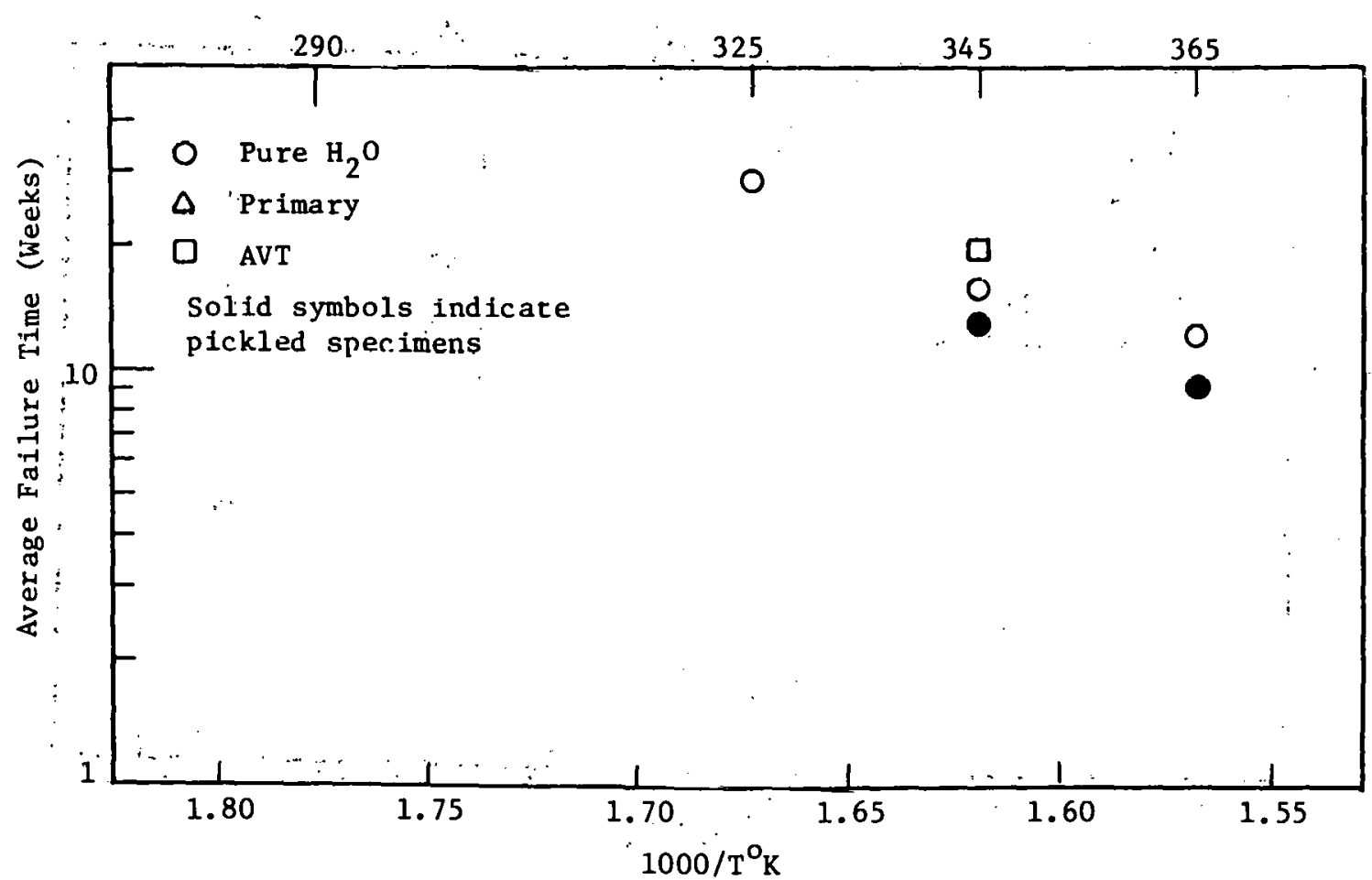

(B)

Fig.1 Effect of environment, surface preparation and temperature on failure time of U-bend specimens (A) Heat $\|_{4}$ (B) Heat $\|_{5}$ 


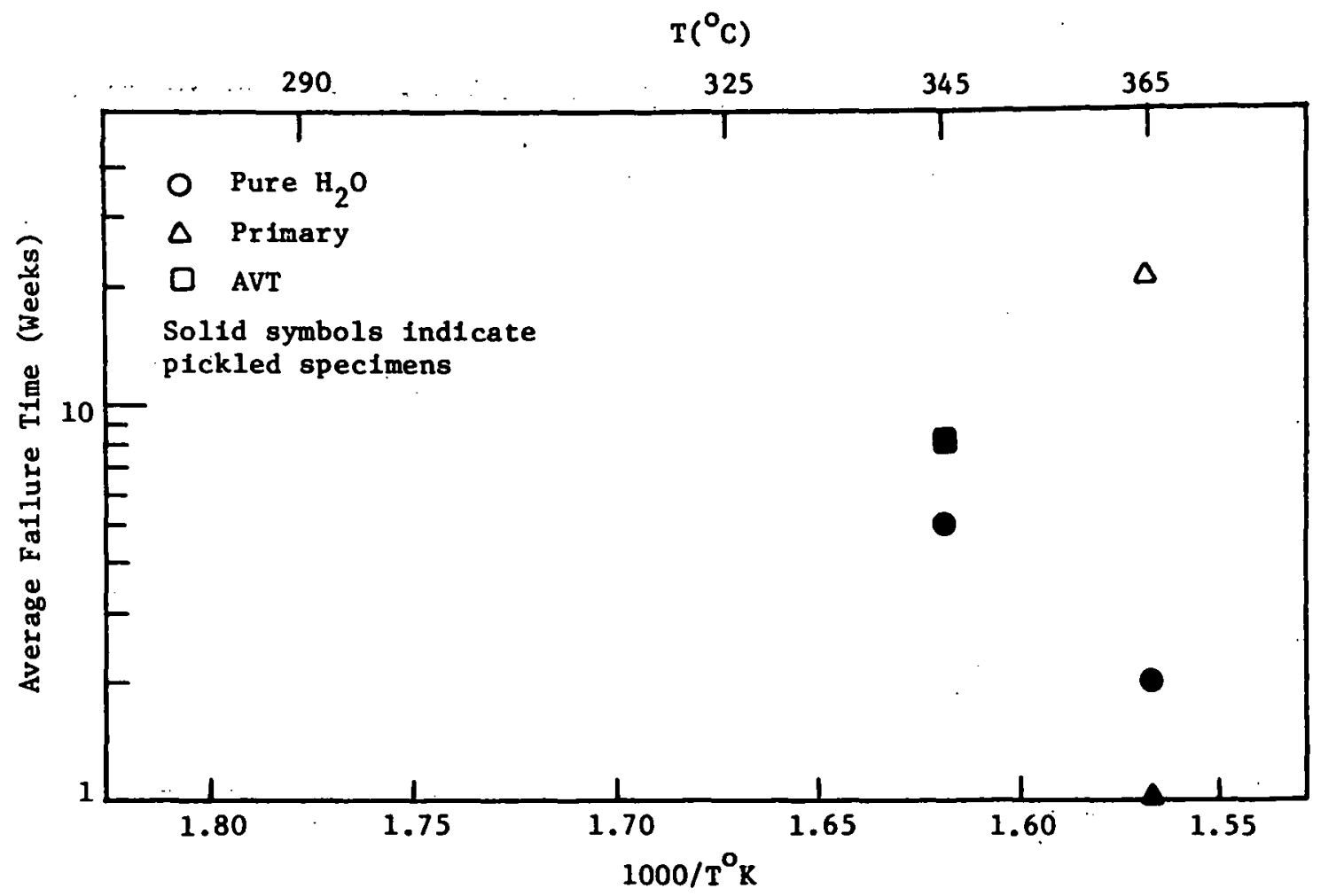

(A)

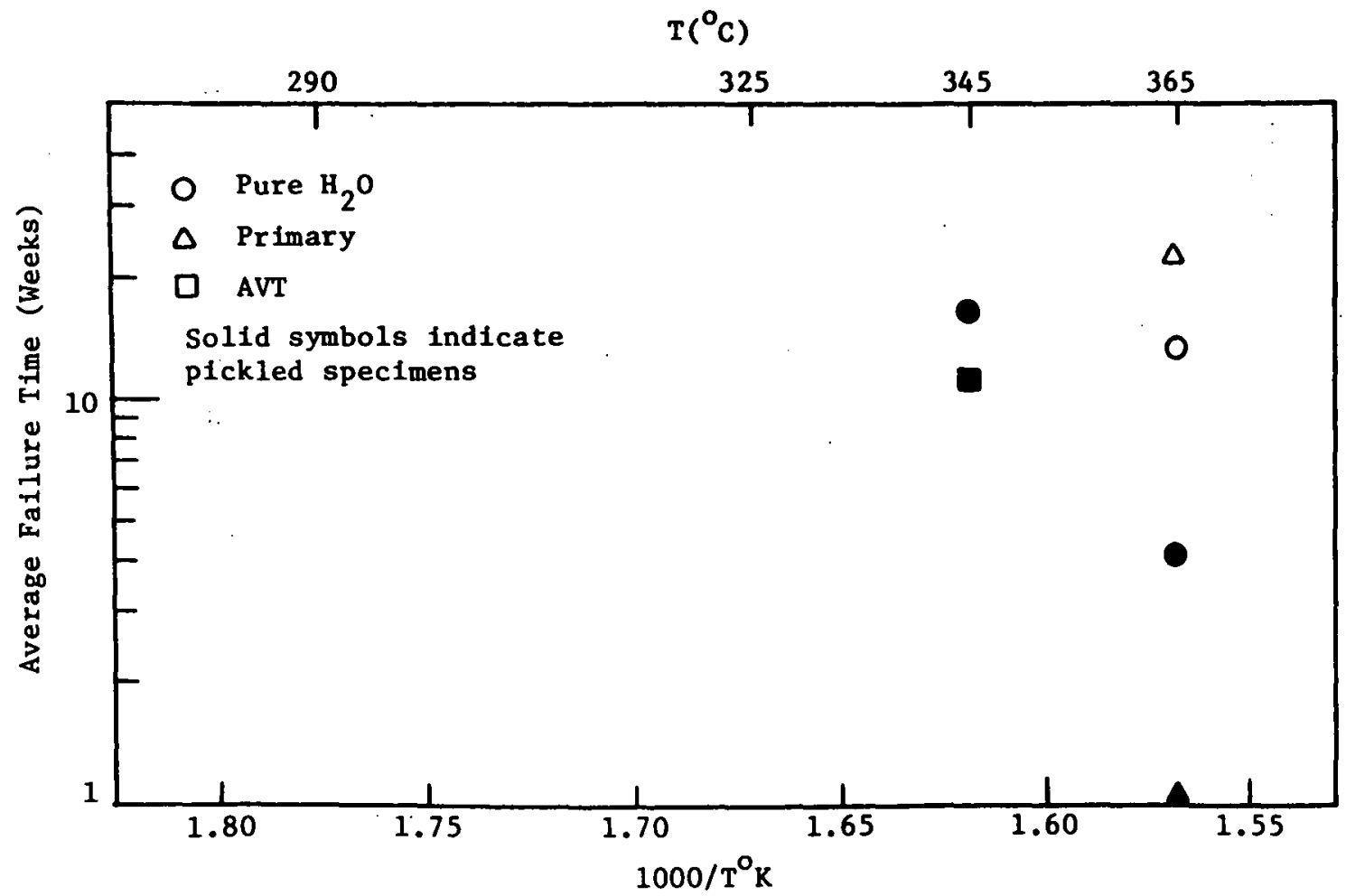

(B)

Fig.2 Ef fect of environment, surface preparation and temperature on failure time of U-bend specimens (A) Heat \#10 (B) Heat \#11 


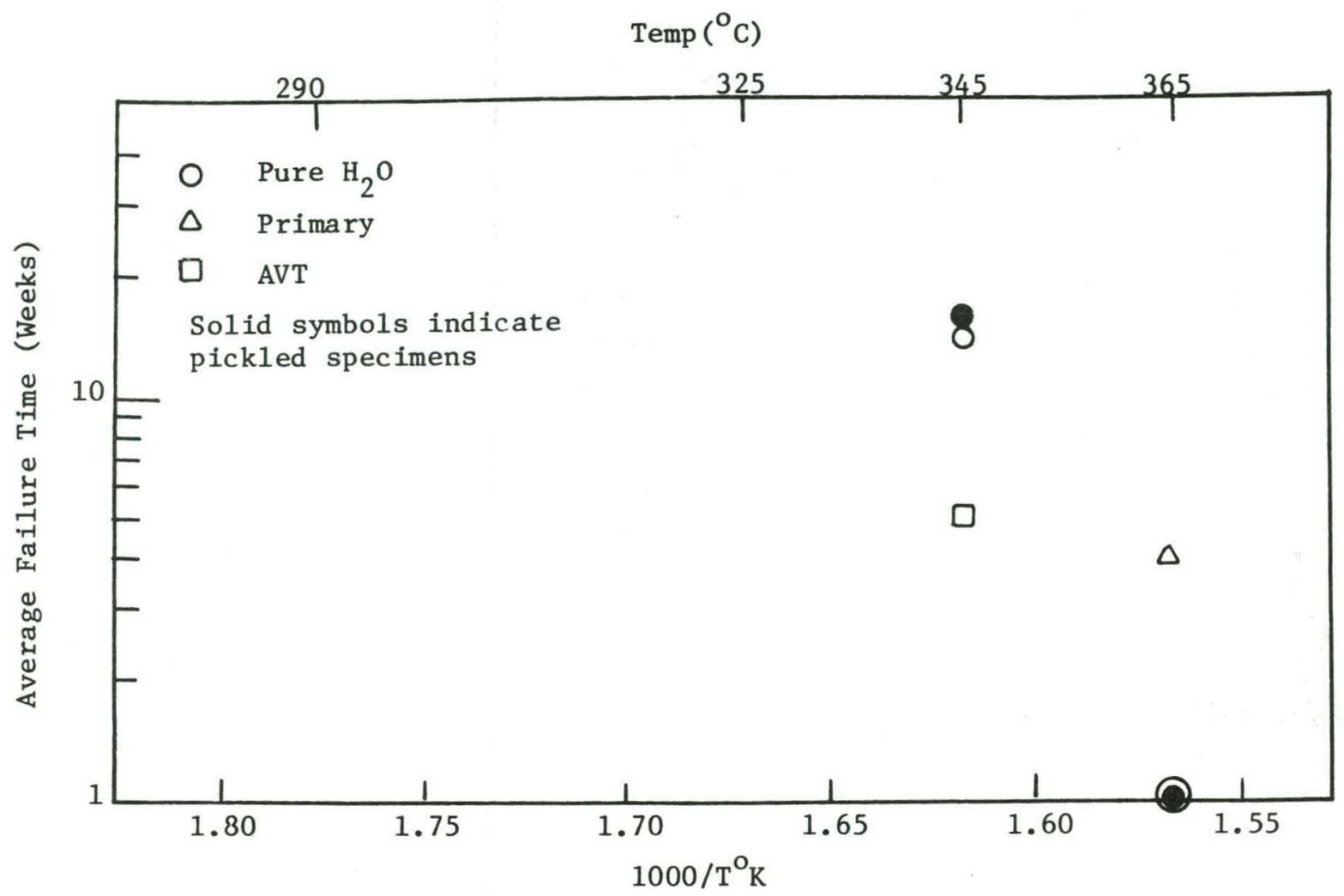

Fig. 3 Effect of environment, surface preparation and temperature on failure time of U-bend specimens Heat $\left.\right|^{2}$

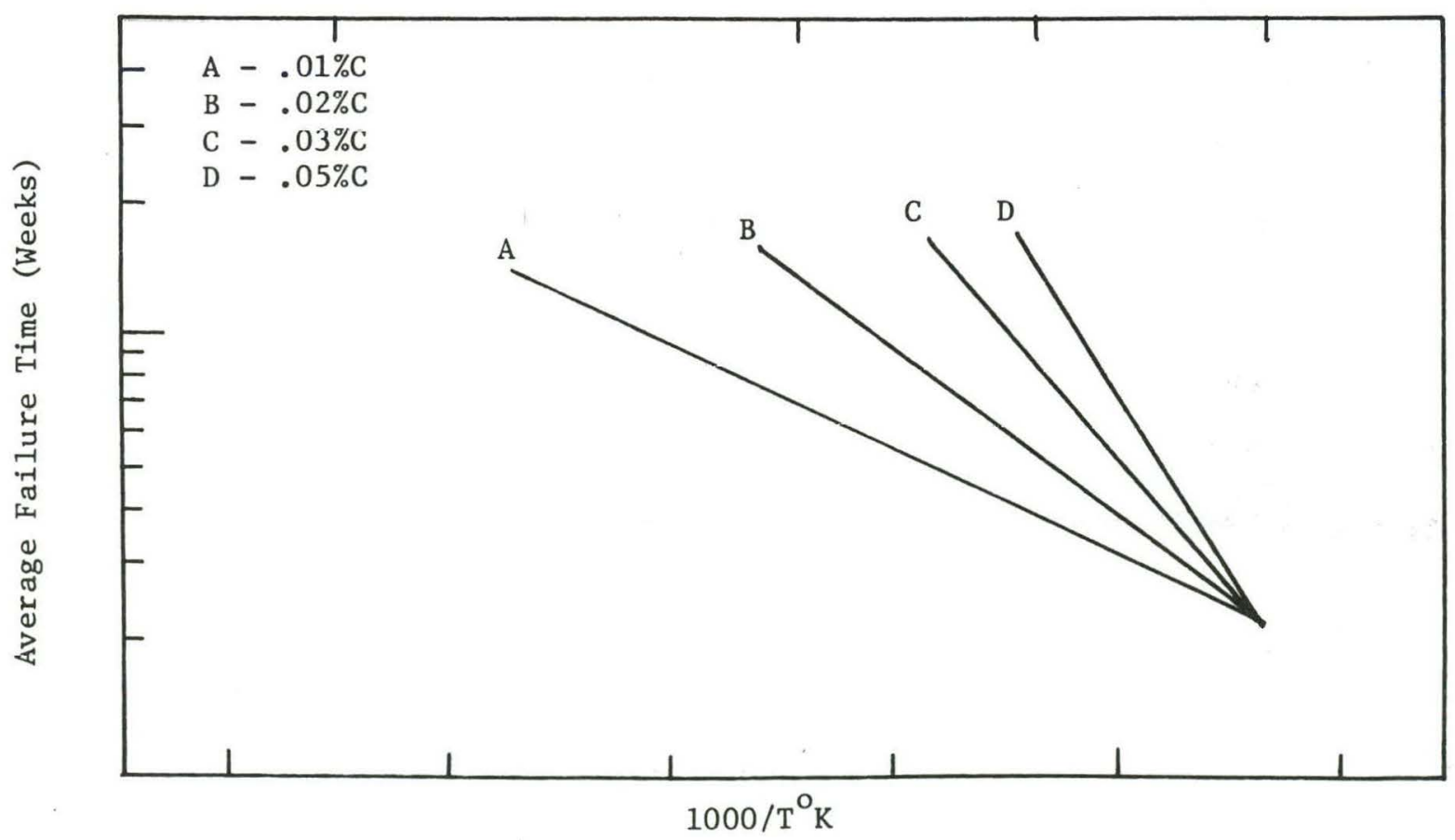

Fig. 4 Fffect of carbon level on time to failure vs. temperature relationship 


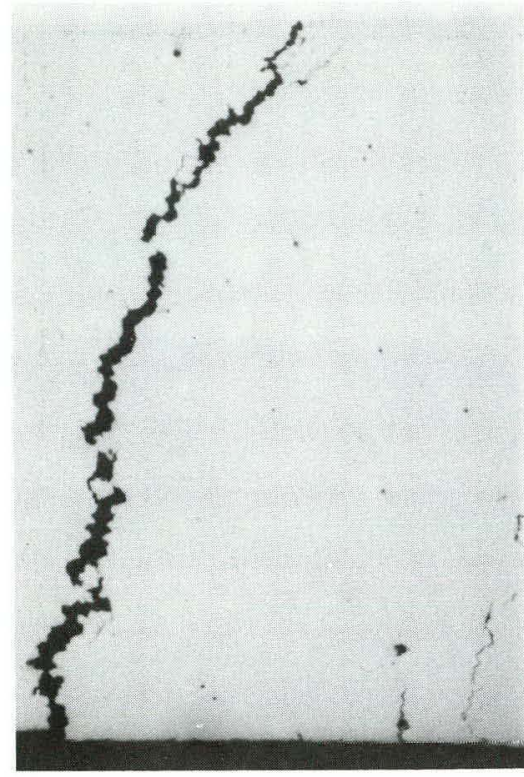

UNETCHED

$68 \mathrm{X}$

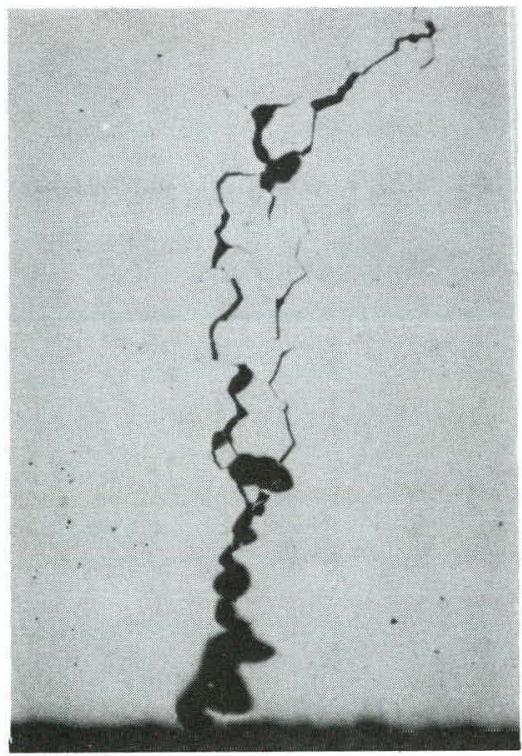

UNETCHED

$68 \mathrm{X}$

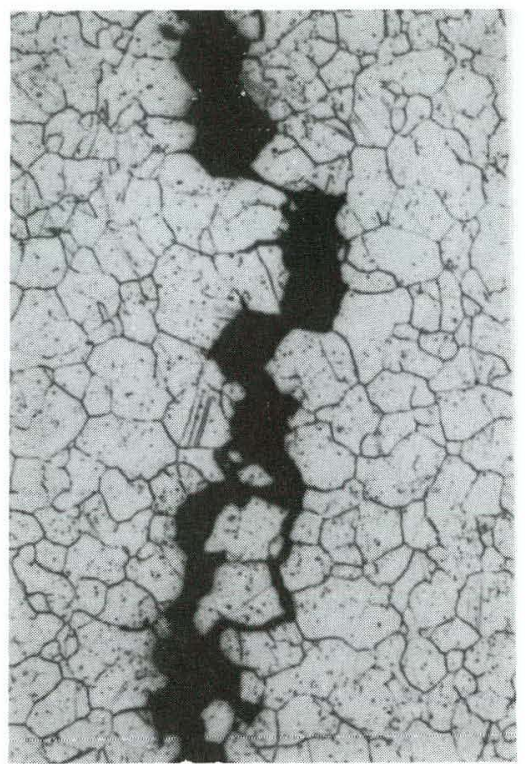

NITAL ETCH

$350 \mathrm{X}$

(A)

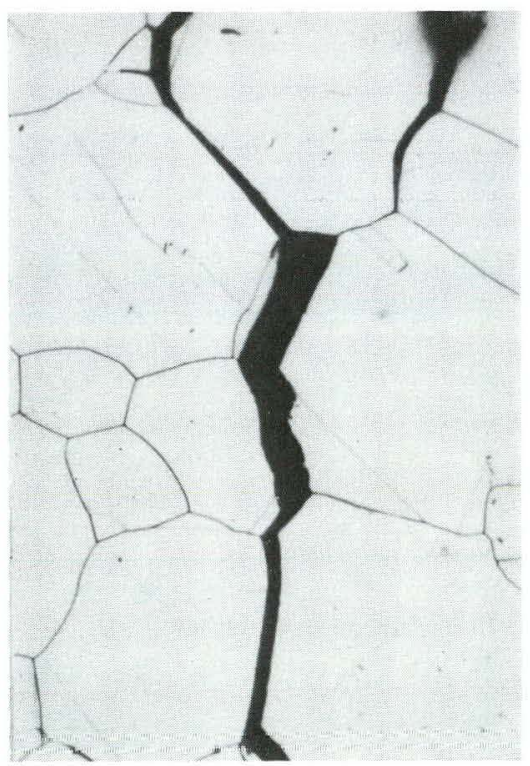

NITAL ETCH

$350 \mathrm{X}$

(B)

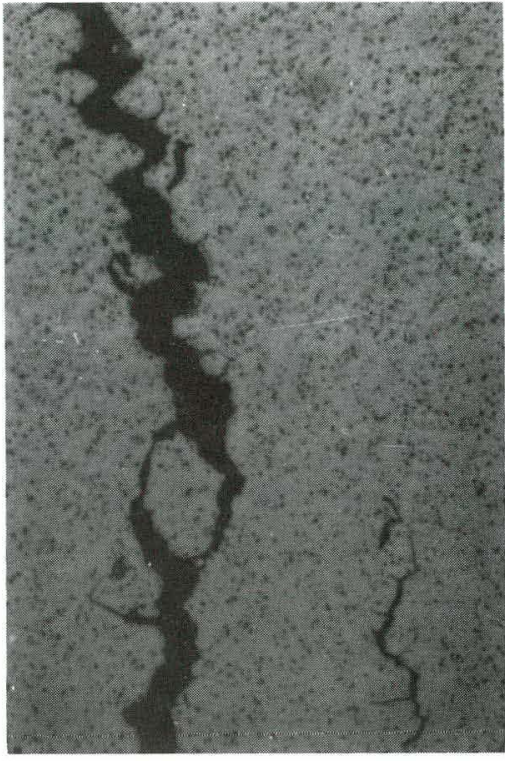

PHOSPHORIC ACID ETCH $350 \mathrm{X}$

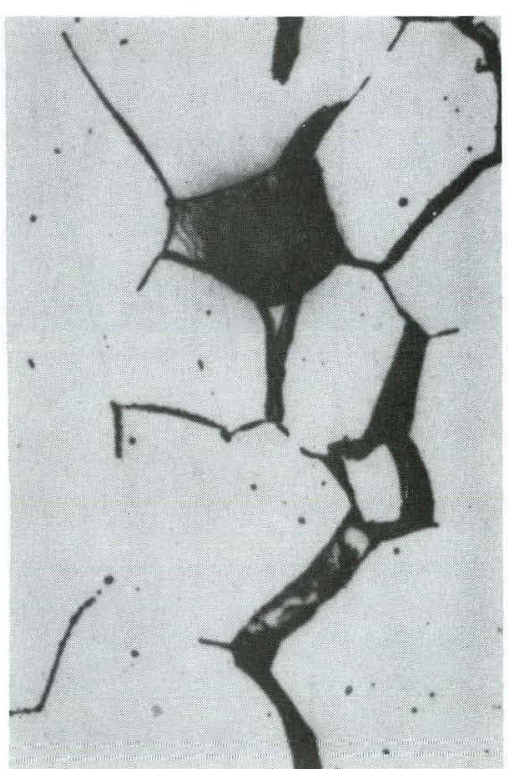

PHOSPHORIC ACID ETCH $350 \mathrm{X}$

Fig. 5 Micrographs of 2 susceptible materials cracked in pure water at $365^{\circ} \mathrm{C}$ (A) Heat 非 2 (B) Heat 非5 


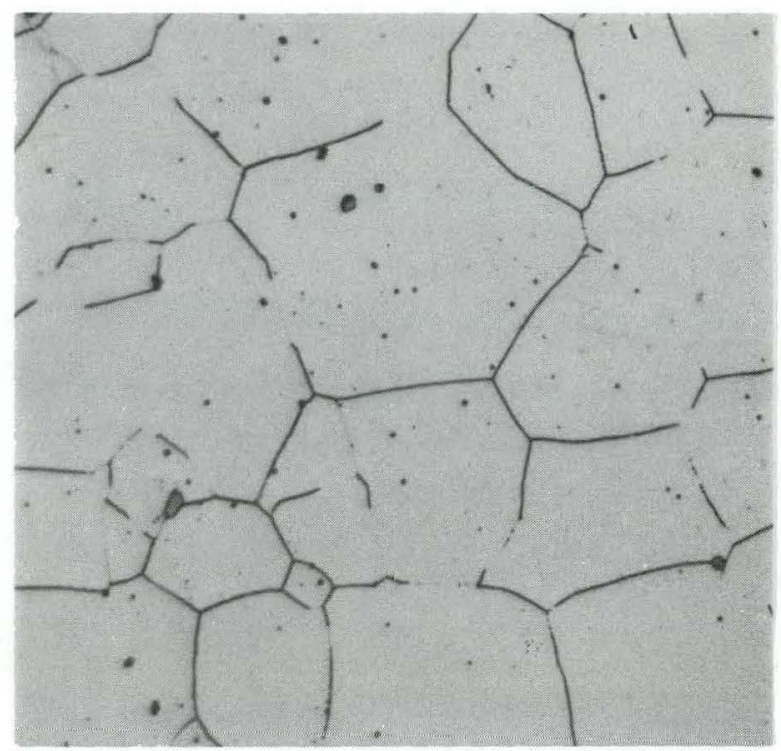

NITAL ETCH

$350 \mathrm{X}$

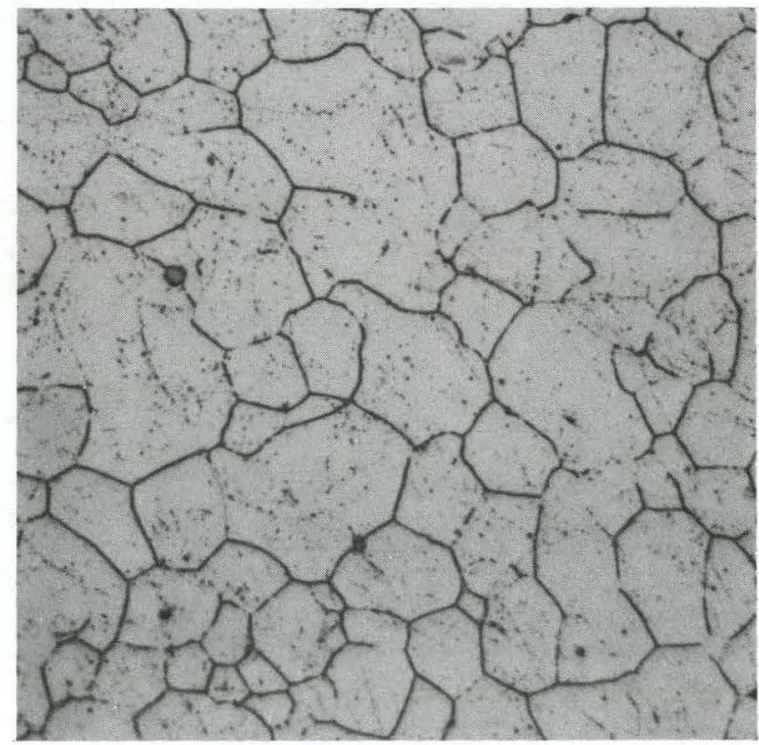

NITAL ETCH

$350 \mathrm{X}$

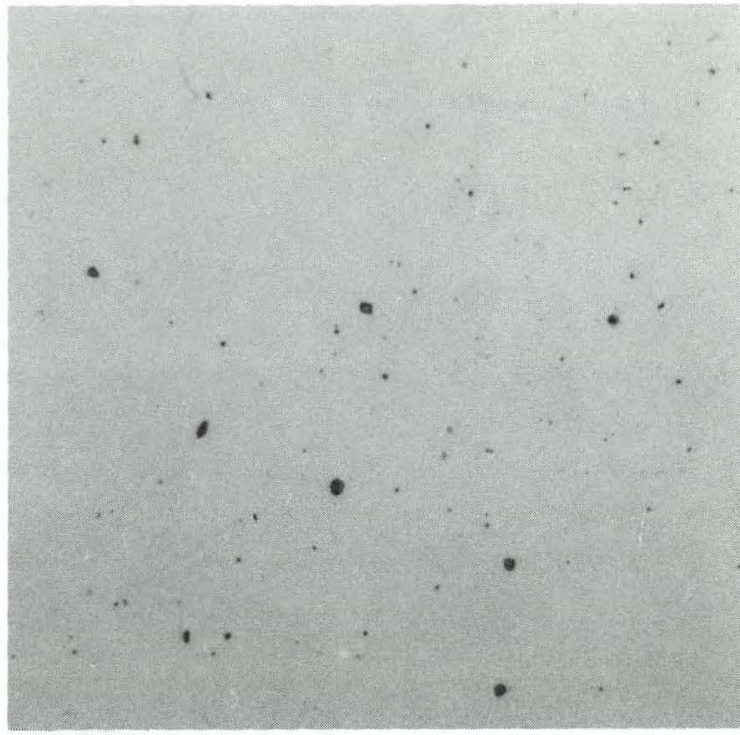

PHOSPHORIC ACID ETCH $350 \mathrm{X}$

(A)

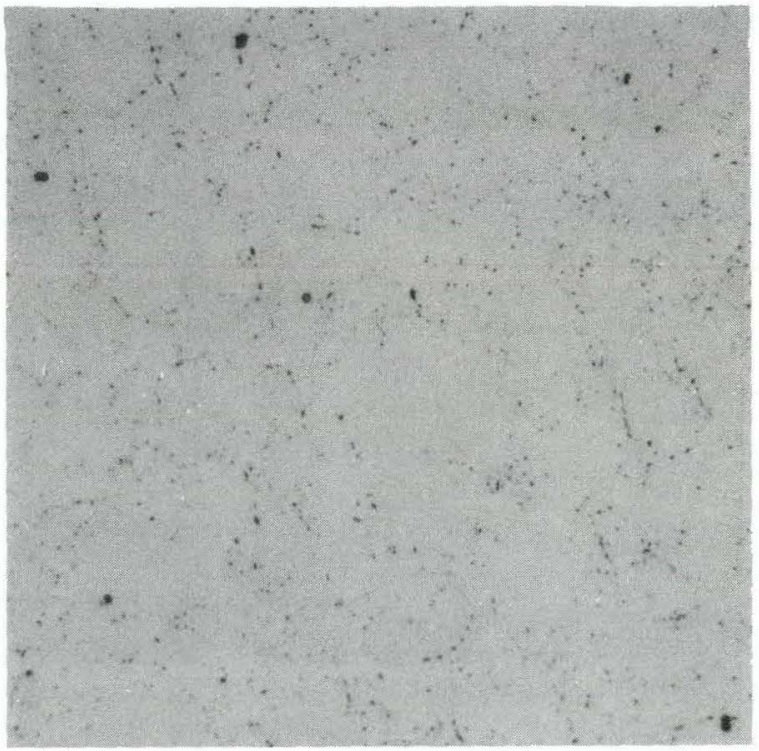

PHOSPHORIC ACID ETCH $350 \mathrm{X}$

Fig. 6 Micrographs of 2 non-susceptible heats of material (A) Heat 非 (B) Heat $\|_{13} 13$ 


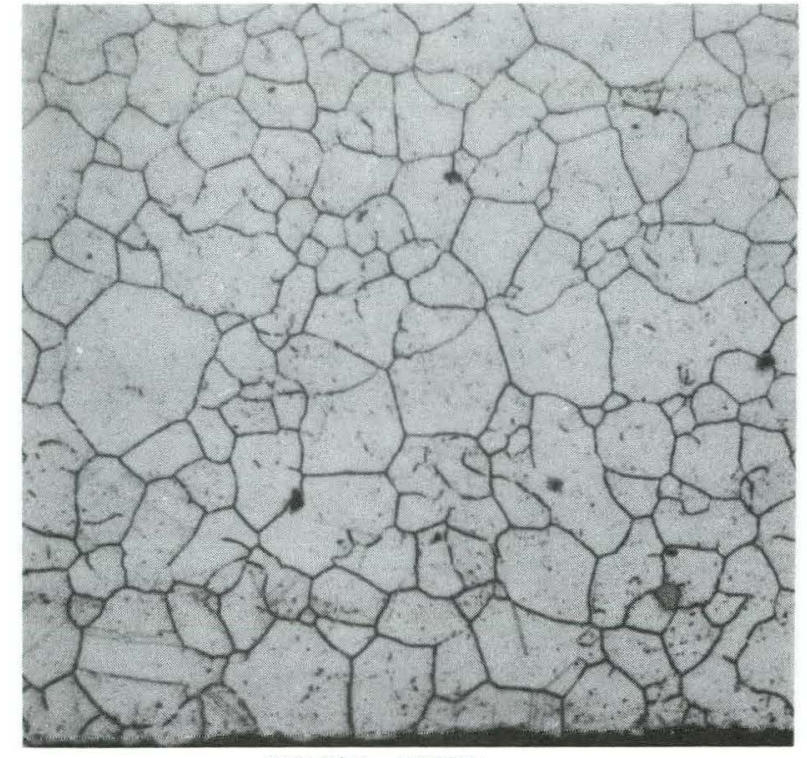

NITAL ETCH

350X

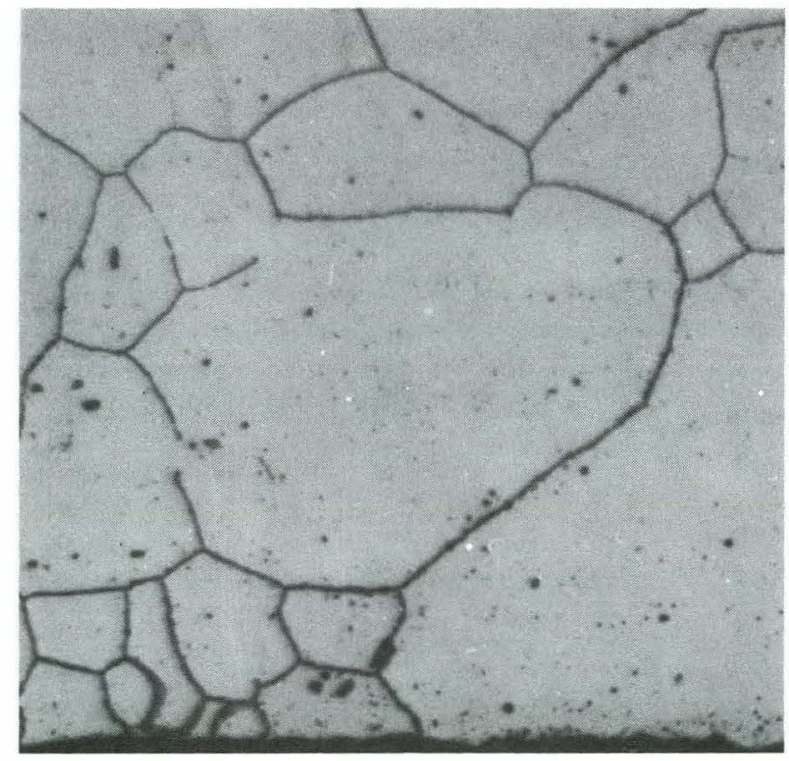

NITAL ETCH

$350 \mathrm{X}$

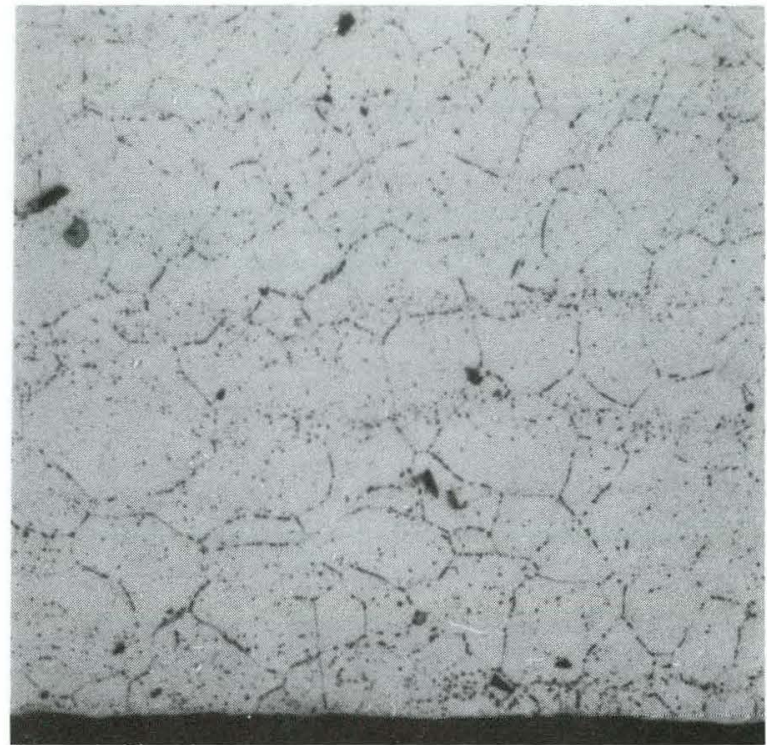

PHOSPHORIC ACID ETCH $350 \mathrm{X}$

(A)

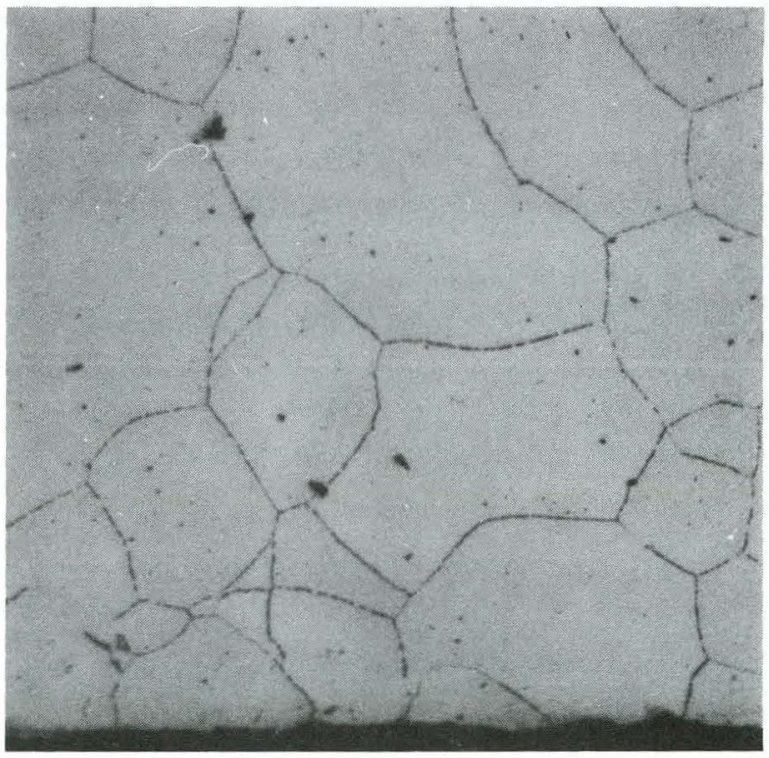

PHOSPHORIC ACID ETCH $350 \mathrm{x}$

(B)

Fig. 7 Structure of recently manufactured material removed from fabrication prior to thermal treatment。 Materials have cracked in AVT and/or primary $\mathrm{H}_{2} \mathrm{O}$ (A) Heat 非18 (B) Heat 非20 


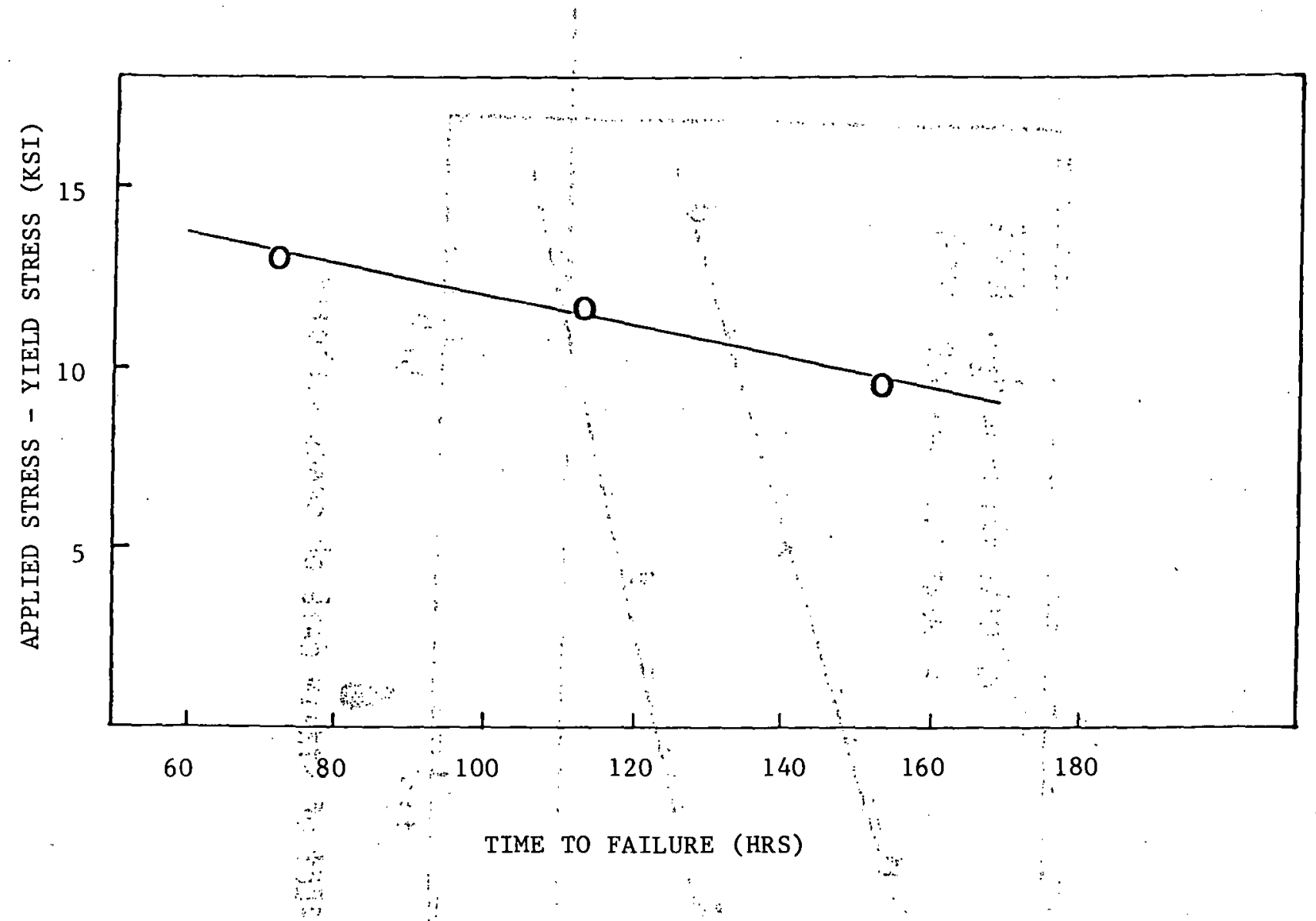

FIG. 8 PRELIMINARY CONSTANT STRESS TEST RESULTS WITH HEAT \#4:

IN D. I. $\mathrm{H}_{2} \mathrm{O}$ a $365^{\circ} \mathrm{C}$

$\because$

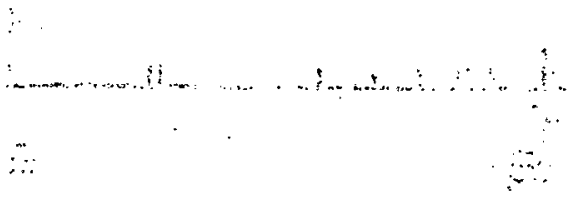

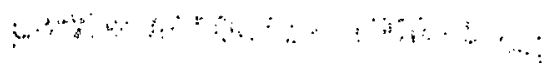




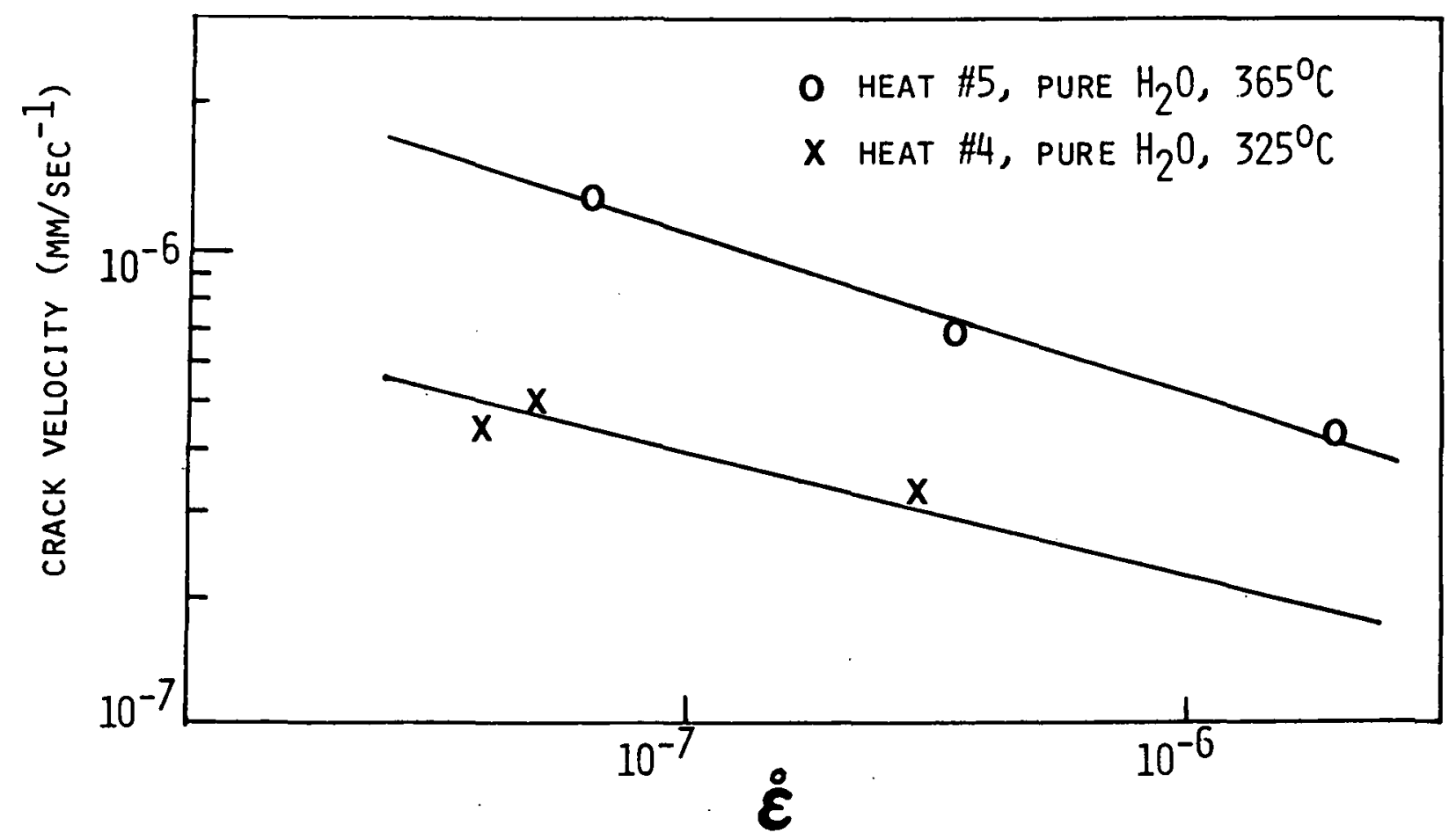

FIG.9 EFFECT OF STRAIN RATE ON CRACK VELOCITY 


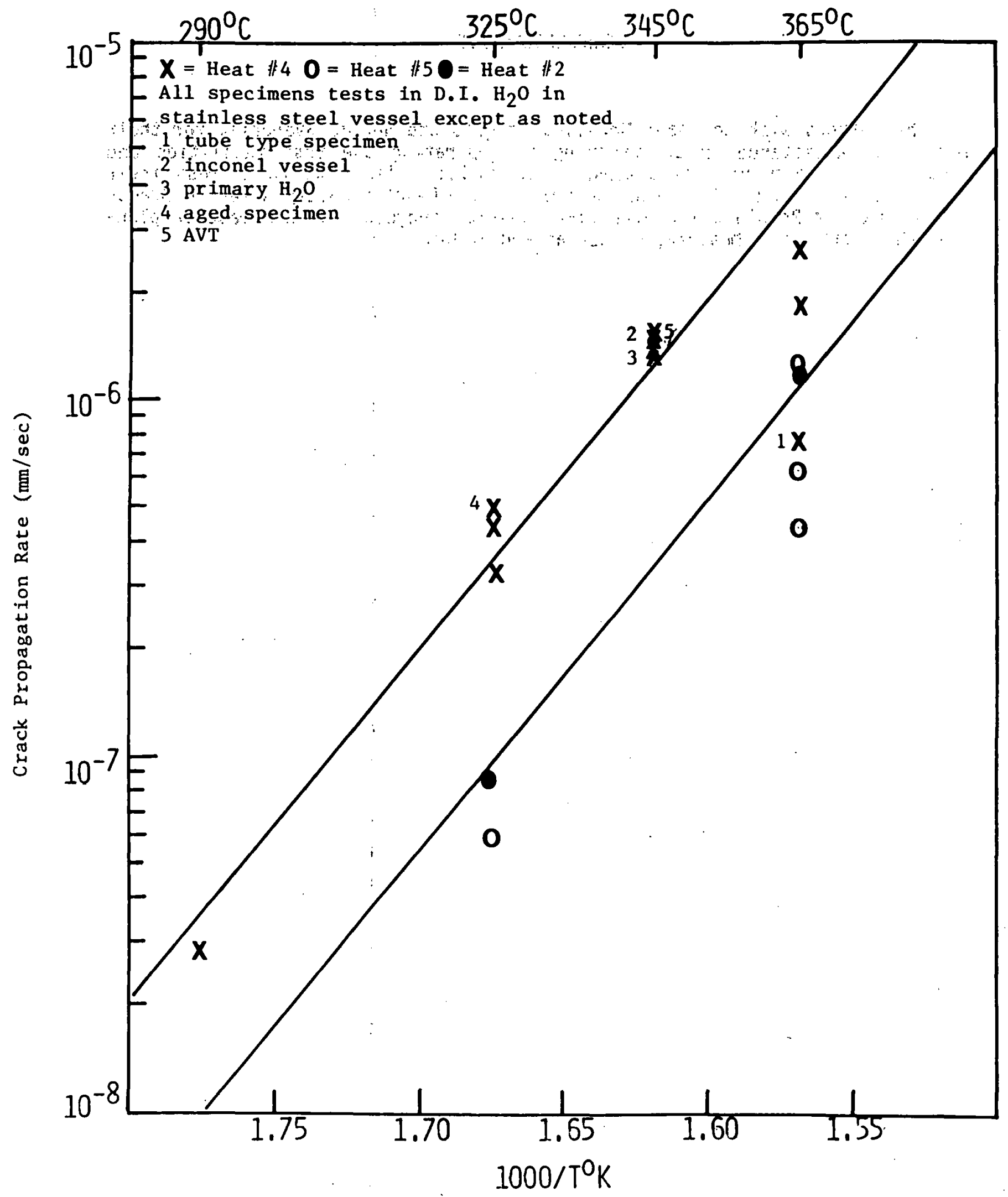

Figure 10 Effect of Temperature on Crack Velocity for Materials Tested in C.E.R.T. 
The authors wish to thank Mr. T.C. Roberts and Mr. J. Svandrlik for their invaluable assistance in constructing and operating the test facilities and preparing and examining specimens. The authors also wish to express their thanks for support of this research work by the Reactor Safety Research Branch of the Nuclear Regulatory commission. Helpful suggestions were made in planning this work by J. Muscara, C. Serpan and P. Wu. 
Division of Reactor Safety Research

L. S. Tong

L. C. Shao

C. Z. Serpan

J. Muscara

P. Wu

Office of Nuclear Reactor Regulation

L. S. Rubenstein

Division of Systems Safety

J. P. Knight

S. S. Pawlicki

R. Gamble

H. F. Conrad

B. Turovl in

Division of Operating Reactors

D. G. Eisenhut

V. Noonan

W. S. Hazelton

B. D. Liaw

F. M. Almeter (5)

BNL

H. J. C. Kouts

W. Y. Kato

D. H. Gurinsky

H. S. Isaacs

Corrosion Science Group (25)

$\underline{\text { MIT }}$

R. Latanision 


\section{RECEIVED BY TIC OCT 101980}

